\title{
The G Protein-Coupled Glutamate Receptors as Novel Molecular Targets in Schizophrenia Treatment- A Narrative Review
}

\author{
Waldemar Kryszkowski ${ }^{1}$ and Tomasz Boczek ${ }^{2, *(D)}$ \\ 1 General Psychiatric Ward, Babinski Memorial Hospital in Lodz, 91229 Lodz, Poland; \\ waldemar.kryszkowski@gmail.com \\ 2 Department of Molecular Neurochemistry, Medical University of Lodz, 92215 Lodz, Poland \\ * Correspondence: tomasz.boczek@umed.lodz.pl
}

Citation: Kryszkowski, W.; Boczek, T. The G Protein-Coupled Glutamate Receptors as Novel Molecular Targets in Schizophrenia Treatment-A Narrative Review. J. Clin. Med. 2021, 10, 1475. https://doi.org/10.3390/ jcm10071475

Academic Editors: Andreas Reif, Blazej Misiak and Jerzy Samochowiec

Received: 2 March 2021

Accepted: 28 March 2021

Published: 2 April 2021

Publisher's Note: MDPI stays neutral with regard to jurisdictional claims in published maps and institutional affiliations.

Copyright: (c) 2021 by the authors. Licensee MDPI, Basel, Switzerland. This article is an open access article distributed under the terms and conditions of the Creative Commons Attribution (CC BY) license (https:// creativecommons.org/licenses/by/ $4.0 /)$.

\begin{abstract}
Schizophrenia is a severe neuropsychiatric disease with an unknown etiology. The research into the neurobiology of this disease led to several models aimed at explaining the link between perturbations in brain function and the manifestation of psychotic symptoms. The glutamatergic hypothesis postulates that disrupted glutamate neurotransmission may mediate cognitive and psychosocial impairments by affecting the connections between the cortex and the thalamus. In this regard, the greatest attention has been given to ionotropic NMDA receptor hypofunction. However, converging data indicates metabotropic glutamate receptors as crucial for cognitive and psychomotor function. The distribution of these receptors in the brain regions related to schizophrenia and their regulatory role in glutamate release make them promising molecular targets for novel antipsychotics. This article reviews the progress in the research on the role of metabotropic glutamate receptors in schizophrenia etiopathology.
\end{abstract}

Keywords: schizophrenia; metabotropic glutamate receptors; positive allosteric modulators; negative allosteric modulators; drug development; animal models of schizophrenia; clinical trials

\section{Introduction}

Schizophrenia is a common debilitating disease affecting about $0.3-1 \%$ of the human population worldwide [1]. Although no convincing evidence about its etiology has been presented so far, it is believed that it has a multifactorial origin involving the combinatorial influence of environmental, genetic, psychological, and social factors. The symptoms of schizophrenia are usually classified into three main groups: positive (e.g., auditory and visual hallucinations, disorganized thought, delusions, odd behaviors), negative (e.g., social withdrawal, flattened affect) and cognitive (e.g., dysfunctions in working memory, attention, visual and verbal learning). Cognitive deficits are among the core symptoms present in almost $98 \%$ of patients with schizophrenia [2]. They usually manifest prior to the onset of psychosis and persist, but evolve during disease development. The antipsychotics currently used in clinical practice can effectively treat positive symptoms, but they poorly address negative and cognitive alterations [3]. Moreover, an increasing number of patients discontinue medical treatment due to extrapyramidal side effects related to the use of first-generation typical antipsychotics or adverse metabolic effects induced by second-generation atypical drugs [4,5]. While most current antipsychotics act on dopaminergic and serotonergic systems, there is an urgent need to identify both new molecules and pharmacological targets with higher safety and efficiency toward core schizophrenia symptoms.

In recent decades, there has been an intensive investigation into the possible role of glutamate in the schizophrenia pathological processes. Glutamate is the main excitatory neurotransmitter in the brain, and its role is inextricably linked to the processes 
related to memory, cognition, or perception [6]. The prevailing glutamatergic theory of schizophrenia postulates hypofunction of N-methyl -D-aspartate receptor (NMDAR) as one of the factors contributing to pathophysiology of this disease [7]. The hypothesis of glutamate involvement is based on the observations of psychotomimetic effects of NMDAR antagonists-phencyclidine (PCP), MK-801 or ketamine, producing all three schizophrenia symptom clusters in healthy individuals $[8,9]$. These findings led to the clinical trials with several prospective drugs, for instance cycloserine or D-serine, positively modulating NMDAR activity [10,11], although their efficacy in schizophrenia was relatively modest.

In addition to NMDAR, AMPA and kainate receptors that mediate most of the excitatory neurotransmission in the central nervous system (CNS), glutamate is also a ligand for $G$ protein-coupled metabotropic receptors. The important subtypes of theses receptors have been demonstrated to be relevant to the symptomology of schizophrenia and other psychiatric disorders such as anxiety and depression [12,13]. They have also been considered putative targets for a novel class of antipsychotics, and several preclinical and clinical trials have been aimed to test their utility and efficacy. Therefore, this review aims to provide an update on the current research status on glutamate metabotropic receptors in the treatment of schizophrenia.

\section{Metabotropic Glutamate Receptors (mGluRs)—An Overview}

Eight genes (GRM1 to GRM8) encoding mGluRs (mGluR1 to mGluR8) have been cloned and characterized, with multiple splice variants that are expressed in different cell types in the central and peripheral nervous system $[14,15]$. Up to date, the genetic loci for each receptor have been identified as well [15]. The mGluRs are divided into three groups I, II and III based on receptor structure, ligand selectivity and physiological action (Table 1). Group I includes mGluR1 and mGluR5, and their activation triggers phospholipase Cmediated effects. Group II, which includes mGluR1 and mGluR3, and group III involving mGluR4,6,7,8, are coupled to the inhibition of cAMP signaling via $G_{i} / G_{0}$ protein (Figure 1). In general terms, these receptors play a modulatory role by regulating neurotransmitter release, excitability, and synaptic plasticity. All glutamate receptors discussed here, except for mGluR6, which is primarily located in the retina, are expressed in neurons and glial cells. However, their distribution in cell subtypes may vary depending on the receptor. 


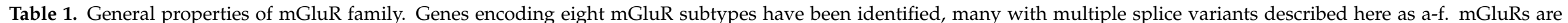

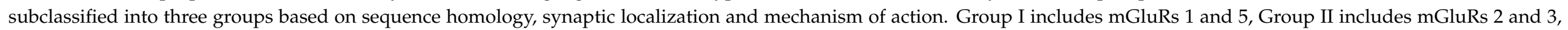
and Group III includes mGluRs 4, 6, 7, and 8.

\begin{tabular}{|c|c|c|c|c|c|}
\hline Group & Receptors/Splice Variants & Gene & Synapse Site & Expression in the CNS & Mechanism of Action \\
\hline \multirow{2}{*}{ Group I } & $\begin{array}{l}\text { mGluR1 } \\
\mathrm{a}, \mathrm{b}, \mathrm{c}, \mathrm{d}, \mathrm{e}, \mathrm{f}\end{array}$ & GRM1 & \multirow{2}{*}{ Mainly postsynaptic } & $\begin{array}{l}\text { Abundant in neurons and } \\
\text { taste buds }\end{array}$ & \multirow{2}{*}{$\begin{array}{l}\text { PLC-dependent } \mathrm{Ca}^{2+} \text { mobilization, stimulation of adenylyl } \\
\text { cyclase (certain systems), activation of MAP kinases, PLD, } \\
\text { mTOR/p70 S6 kinase }\end{array}$} \\
\hline & $\underset{\mathrm{a}, \mathrm{b}}{\mathrm{mGluR5}}$ & GRM5 & & $\begin{array}{l}\text { Abundant in neurons } \\
\text { and astrocytes }\end{array}$ & \\
\hline \multirow[b]{2}{*}{ Group II } & mGluR2 & GRM2 & \multirow[b]{2}{*}{$\begin{array}{l}\text { Presynaptic and } \\
\text { postsynaptic }\end{array}$} & Abundant in neurons & \multirow[b]{2}{*}{$\begin{array}{l}\text { Inhibition of adenylyl cyclase and voltage-dependent } \mathrm{Ca}^{2+} \\
\text { channels, activation of voltage-dependent } \mathrm{K}^{+} \text {channels [16], } \\
\text { MAPK and PI3 kinase pathway [17] }\end{array}$} \\
\hline & $\begin{array}{c}\text { mGluR3 } \\
\text { GRM3A2 } \\
\text { GRM3A4 } \\
\text { GRM3A2A3 }\end{array}$ & GRM3 & & $\begin{array}{l}\text { Abundant in neurons } \\
\text { and astrocytes }\end{array}$ & \\
\hline \multirow{3}{*}{ Group III } & mGluR4 & GRM4 & \multirow{3}{*}{$\begin{array}{l}\text { Mainly presynaptic } \\
\text { (mGluR6 is } \\
\text { postsynaptic in ON } \\
\text { bipolar retinal cells) }\end{array}$} & $\begin{array}{l}\text { Abundant in neurons (high in } \\
\text { cerebellum) and taste buds }\end{array}$ & \multirow{3}{*}{$\begin{array}{l}\text { Inhibition of adenylyl cyclase, inhibition of } \\
\text { voltage-dependent } \mathrm{Ca}^{2+} \text { channels, activation of } \mathrm{K}^{+} \\
\text {channels [16], activation of cGMP phosphodiesterase [18] } \\
\text { (mGluR6), MAPK and PI3 kinase pathway [17] }\end{array}$} \\
\hline & $\begin{array}{c}\text { mGluR6 } \\
\text { a,b,c }\end{array}$ & GRM6 & & Retina & \\
\hline & $\begin{array}{l}\text { mGluR7 } \\
\mathrm{a}, \mathrm{b}, \mathrm{c}, \mathrm{d}, \mathrm{e}\end{array}$ & GRM7 & & Abundant in neurons & \\
\hline
\end{tabular}




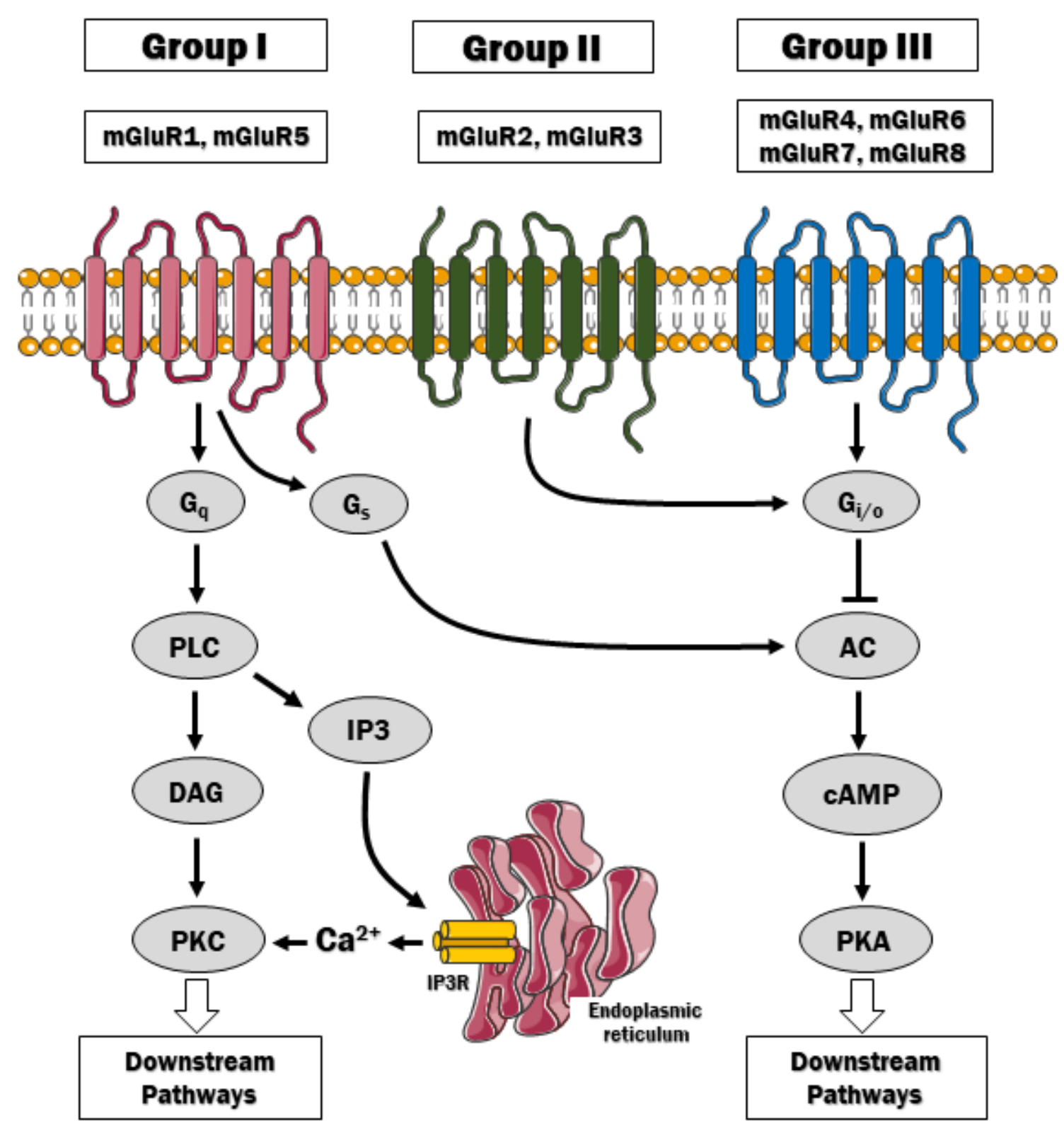

Figure 1. The signaling pathways downstream mGluRs. Group I mGluR is coupled to $\mathrm{G}_{\mathrm{q}}$ protein, which stimulates phospholipase C (PLC) and the hydrolysis of phosphatidylinositol 4,5-bisphosphate $\left(\mathrm{PIP}_{2}\right)$. $\mathrm{PIP}_{2}$ hydrolysis gives rise to inositol $(1,4,5)$-triphosphate $\left(\mathrm{IP}_{3}\right)$ and diacylglycerol (DAG). The $\mathrm{IP}_{3}$ diffuses freely to the endoplasmic reticulum and activates the $\mathrm{IP}_{3}$ receptors to release $\mathrm{Ca}^{2+}$ to the cytosol. By contrast, mGluRs of group II and III classically couple to $\mathrm{G}_{\mathrm{i} / \mathrm{o}}$ proteins and inhibit adenylyl cyclase, thus affecting downstream signaling pathways via liberation of $G \beta \gamma$.

\section{Group I mGluRs}

\subsection{Biology of Group I mGluRs}

In general, the mGluRs in group I (mGluR1 and mGluR5) are associated with the $\mathrm{G}_{\mathrm{q}} / \mathrm{G}_{11}$-mediated signaling pathway and are strongly stimulated by L-quisqualic acid, which is thought to mimic the excitatory action of L-glutamic acid [19]. The classical pathway downstream these receptors includes activation of phospholipase $C \beta$, resulting in hydrolysis of plasma-membrane inserted phosphoinositide phospholipids and generation of inositol 1,4,5-trisphosphate $\left(\mathrm{IP}_{3}\right)$ and diacylglycerol (DAG). $\mathrm{IP}_{3}$ diffuses to the ER, where upon binding to $\mathrm{IP}_{3}$ receptors, it allows for $\mathrm{Ca}^{2+}$ efflux and its mobilization in the cytosol. A growing body of evidence indicates that these receptors can also act 
through cascades downstream of $G_{q}, G_{i} / o$ and $G_{s}$ or independent of $G$ proteins [20-23]. These downstream effectors include, for instance, cyclin-dependent protein kinase 5 [24], extracellular signal-regulated kinase [25], c-Jun N-terminal kinase [26], casein kinase I [27], phospholipase D [28], mammalian target of rapamycin (mTOR)/p70 S6 kinase pathway or CREB (cAMP response element binding protein)-dependent signaling [29]. The coupling of these receptors to variety of signal-transducing pathways and their close association with NMDA receptors via scaffolding proteins Homer, SHANK, and GKAP-PSD95 [30] make them attractive targets for pharmacological interventions in schizophrenia.

Because mGluRs of group I are located predominantly postsynaptically, their activation results in neuronal depolarization, although mGluR1's ability to elicit hyperpolarization was demonstrated in midbrain dopaminergic neurons [15]. Of relevance to schizophrenia, mGluR1/5 can influence both post- and presynaptic NMDA receptor currents, and this bidirectional regulation depends on calcium [31]. When intracellular $\mathrm{Ca}^{2+}$ concentration rises, activation of mGluR1/5 decreases NMDA receptor activity to provide control over abnormal, and potentially detrimental, $\mathrm{Ca}^{2+}$ increases. Group I mGluRs can also regulate postsynaptic excitability within the frontal cortex, thalamus, striatum, hippocampus and subthalamic nucleus, the brain structures associated with schizophrenia pathology [31,32]. Genetic and behavioral studies discussed below significantly contributed to our understanding of these receptors' function in cognitive and sensomotoric processes relevant to schizophrenia.

\section{2. $m$ GluR1}

The contribution of mGluR1 to schizophrenia was shown by postmortem studies which revealed increased expression of this receptor in the prefrontal cortex of schizophrenia subjects [33]. Further support was provided by Brody and Geyer, who demonstrated disruption of prepulse inhibition in mGluR1 ${ }^{-/-}$mice, which was ameliorated by mood stabilizer lamotrigine [34]. By contrast, mGluR1 antagonists selectively increased the basal level of prepulse inhibition in a mice model of sensorimotor gating impairment [35], a brain process that is typically altered in schizophrenic patients [36].

Genome-wide association studies identified 12 rare deleterious mutations in the GRM1 gene [37,38], and those mutations associated with schizophrenia also reduced mGluR1 signaling. However, the mutant receptors can be potentiated by series of small molecules developed by Cho and colleagues that have the efficacy to restore, at least partially, glutamate-mediated calcium signaling [39]. This suggests that schizophrenia deficits produced by these mutated receptors can be handled by mGluR1 positive allosteric modulators (PAM).

An increasing number of studies suggest that mGluR1 PAMs could be applied in treating positive and cognitive symptoms of schizophrenia what is consistent with the hypothesis of mGluR1 contribution to the regulation of long-term potentiation (LTP) [40-42]. Besides the potential utility of PAMs, it has been reported that also negative allosteric modulators (NAM) of mGluR1 can be efficient in reducing NMDAR-induced hyperlocomotion, deficits in prepulse inhibition, and social interactions in animal models of schizophrenia (Table 2) [42-44]. 
Table 2. Summary of the preclinical studies on mGluR1/5 ligands.

\begin{tabular}{|c|c|c|c|c|}
\hline Target & Tested Drug & Animal Model & Results & References \\
\hline \multirow{3}{*}{ mGluR1 } & CFMTI & $\begin{array}{l}\text { ketamine- and } \\
\text { metAMPH-induced model }\end{array}$ & $\begin{array}{l}\text { CFMTI reduced ketamine- and metAMPH-induced } \\
\text { hyperlocomotion and drug-induced deficits in prepulse inhibition }\end{array}$ & [45] \\
\hline & CFMTI & MK-801-induced model & Ameliorated MK-801-disrupted social interactions & [45] \\
\hline & FTIDC & metAMPH-induced model & $\begin{array}{l}\text { Reduced metAMPH-evoked hyperlocomotion and ameliorated } \\
\text { deficits in prepulse inhibition }\end{array}$ & [43] \\
\hline \multirow{6}{*}{ mGluR5 } & MPEP & PCP-induced model & $\begin{array}{c}\text { Potentiated the psychotomimetic, cognition impairing and prepulse } \\
\text { inhibition-disruptive effects of PCP. }\end{array}$ & {$[44,46]$} \\
\hline & CHPG & $\begin{array}{l}\text { MK-801-induced model } \\
\text { Ketamine-induced model }\end{array}$ & $\begin{array}{l}\text { CHPG reversed the cognitive-impairing effects of NMDA receptor } \\
\text { antagonists and attenuated ketamine-induced locomotor activity, } \\
\text { motor coordination and deficits in prepulse inhibition }\end{array}$ & {$[47,48]$} \\
\hline & CDPPB & AMPH-induced model & $\begin{array}{l}\text { Reduced AMPH-induced hyperlocomotion and ameliorated } \\
\text { AMPH-disrupted prepulse inhibition }\end{array}$ & [49] \\
\hline & CDPPB & MK-801-induced model & $\begin{array}{l}\text { Attenuated MK-801-induced decrease in sucrose preference and } \\
\text { deficits in cognitive flexibility }\end{array}$ & {$[50,51]$} \\
\hline & ADX47273 & $\begin{array}{l}\text { PCP- and AMPH-induced } \\
\text { model }\end{array}$ & $\begin{array}{c}\text { ADX47273 blocked PCP- and AMPH-induced locomotor activity } \\
\text { and decreased extracellular dopamine level in the } \\
\text { nucleus accumbens }\end{array}$ & [52] \\
\hline & VU0409551 & $\begin{array}{l}\text { AMPH-induced model } \\
\text { MK-801-induced model }\end{array}$ & Reduced AMPH- and MK-801-induced hyperlocomotion & {$[53,54]$} \\
\hline
\end{tabular}

\section{3. $m$ GluR5}

A growing body of evidence indicates that mGluR5 is an attractive pharmacological target to treat schizophrenia. CDPPB, the first mGluR5 PAM with favorable drug metabolism and pharmacokinetic properties, reversed amphetamine-induced hyperlocomotion and disruption of prepulse inhibition in rats (Table 2) [49]. Another mGluR5 agonist, VU0409551, produced rapid antipsychotic-like and cognition-enhancing activity in rodent models of schizophrenic symptoms. It selectively potentiated mGluR5 coupling to G $\alpha$-mediated calcium mobilization and ERK1/2 signaling but not mGluR5 modulation of NMDA receptor currents in CA1 pyramidal cells [53]. This is in agreement with the ability of the drug to enhance long-term depression (LTD) at the Schaffer-Collateral-CA1 synapse induced by (S)-3,5-dihydroxyphenylglycine, a form of plasticity that requires ERK (extracellular signal-regulated kinase) activity [30].

VU0409551 is also useful in reversing the deficits in serine racemase (SR) knockout mice, in which the synthesis of D-serine is genetically ablated [55]. SR, the enzyme that produces the NMDA receptor co-agonist, has been recently identified as a risk gene for schizophrenia [11], and the $\mathrm{SR}^{-/-}$mice mimic many behavioral and neurochemical abnormalities observed in this disease. VU0409551 was shown to enhance NMDA receptor function, rescue long-tern potentiation in hippocampal slices from $\mathrm{SR}^{-/-}$mice and improve contextual fear memory [55]. Therefore, modulation of mGluR 5 can be considered an effective mechanism to improve synaptic plasticity and memory impairments in schizophrenia.

\section{Group II mGluRs}

\subsection{General Characteristics}

Among mGluRs belonging to group II, the expression of mGluR2 is restricted to only a few brain regions including cerebellar cortex and the olfactory bulbs. The mGluR3 is more widely expressed and is extensively detected in dentate gyrus, cerebral cortex, striatum, cerebellar cortex, substantia nigra pars reticulata, olfactory tubercle and lateral septal nucleus [56]. In these structures, mGluR3 localization is either presynaptic, postsynaptic, or glial $[57,58]$. In contrast, mGluR2 is found only in neurons acting at the preterminal region away from the sites of neurotransmitter release [56]. Presynaptic mGluR2/3 are targeted to the membrane regions distant form the synaptic cleft, where they transduce signals induced by synaptic or astrocytic glutamate release [30]. 
In contrast to group I, glutamate receptors belonging to group II are mostly coupled to $G_{i / o}$ proteins, which in turn inhibit cAMP signaling, certain calcium channels and other downstream pathways via $G_{\beta \gamma}$ subunits. These receptors also couple extracellular glutamate signaling to MAPK and PI3 kinase activity, thus expanding the complexity of mechanisms by which they may contribute to synaptic defects in schizophrenia [15]. Moreover, as mGluRs 2/3 primary function to inhibit neurotransmitter secretion form various type of synapses (GABAergic, glutamatergic, dopaminergic, etc.), they have gained an attention as effective pharmacological targets for novel antipsychotics. It is now becoming apparent that these mGluRs do not act in isolation, rather they crosstalk with other mGluRs. For instance, formation of mGluR2/mGluR4 heterodimer is known to regulate the interaction of both receptors with allosteric ligands [59]. By contrast, mGluR3 supports mGluR5-dependent signaling in cortical pyramidal neurons without forming a heterodimeric complex [60].

\section{2. $m$ GluR2/3 Function in Schizophrenia}

It has been demonstrated that activation of mGluR2/3 attenuates amphetamineinduced dopamine release in the dorsal striatum, nucleus accumbens and substantia nigra via a mechanism independent from vesicular release or de novo synthesis or reuptake of dopamine [61]. Pharmacological activation of these receptors also reduced some of the behavioral and cellular deficits of NMDA receptor hypofunction in animal models of schizophrenia. These included normalization of locomotor activity, reduction of the frequency of stereotypic behaviors [62,63] and improvement of working memory [62,64]. Presynaptic mGluR2/3 usually provide negative feedback on glutamate action. In line with that attenuation of glutamate release in the medial prefrontal cortex (mPFC) induced by NMDA receptor antagonist-ketamine was seen in the presence of mGluR2/3 agonists [65]. In glia, however, they potentiate synaptic glutamate uptake acting on glial glutamate transporters [66]. Postsynaptic $m G l u R 2 / 3$ receptors have also been localized to dendritic spines of hippocampal dentate granule cells in a close proximity to glutamatergic synapses [67] suggesting their role in increasing neuronal excitability, as was shown for mGluR3 in CA3 pyramidal neurons [67]. It is still unclear whether this enhancement (either NMDA receptor current or other currents) is associated with the antipsychotic potency of mGluR2/3 agonists but undoubtedly, they can provide normalization of glutamate levels and NMDA receptor function in schizophrenia.

A growing body of evidence also indicates that postsynaptic mGluR2/3 may play a pivotal role in the layer III circuits of the dorsolateral prefrontal cortex, the structure which is associated with executive functions including working memory and selective attention. The modulatory role of GluR2/3 toward glutamate release provides a rationale for developing selective PAMs and NAMs to counterbalance the excessive glutamate tone in the brain of schizophrenia individuals. However, as will be discussed in the subsequent sections, the outcome of clinical trials were mixed, highlighting the further need for understanding the contribution of GluR2/3 to disease development and progression.

Gonzalez-Maeso and colleagues reported that 5-HT2A serotonin receptor and mGluR2 are co-expressed in the same population of cortical neurons and are implicated in psychosis associated with schizophrenia [68]. This was based on the observation that 2AR-mGluR2 complexes targeted by hallucinogenic drugs activated unique cellular and behavioral response, which was blunted by the activation of mGluR2. In support, mGluR2 knockout mice were insensitive to behavioral effects of hallucinogenic drugs [69], further suggesting that 2AR-mGluR2 complex, but not 5-HT2A receptor alone, is obligatory for neuropsychological responses to hallucinogens. Postmortem analysis of untreated schizophrenic brains revealed up-regulation of 5-HT2A receptor and concomitant down-regulation of mGluR2, a pattern that could predispose to psychosis [68]. On the other hand, antagonism of 5-HT2A with atypical antipsychotics has been shown to affect mGluR2 expression in rodents [70], which may raise an issue about therapeutic efficacy of mGluR2 ligands in patients treated with atypical serotonergic antipsychotics. 


\subsection{Targeting mGluR2/3 in Schizophrenia Treatment}

\subsubsection{Preclinical Studies}

The potential use of mGluR2/3 agonists in the treatment of schizophrenia was heavily tested in pre-clinical studies using different animal models (Table 3).

Table 3. Summary of the preclinical studies on mGluR2/3 ligands.

\begin{tabular}{|c|c|c|c|}
\hline Tested Drug & Animal Model & Results & References \\
\hline LY379268 & PCP- and AMPH-induced model & $\begin{array}{l}\text { LY379268 reversed PCP and AMPH-induced hyperactivity and } \\
\text { PCP-evoked behavioral deficits }\end{array}$ & [71] \\
\hline $\begin{array}{l}\text { LY354740 } \\
\text { LY379268 }\end{array}$ & PCP- and AMPH-induced model & $\begin{array}{l}\text { LY354740 and LY379268 attenuated PCP- but not AMPH-induced } \\
\text { motor behaviors }\end{array}$ & [72] \\
\hline LY379268 & AMPH-induced model & $\begin{array}{l}\text { LY379268 attenuated AMPH-induced ambulations and rearing but not } \\
\text { fine motor movements }\end{array}$ & [73] \\
\hline LY379268 & PCP-induced model & $\begin{array}{l}\text { LY379268 reduced PCP-induced falling, turning, and back pedaling in a } \\
\text { dose-dependent manner but did not affect PCP-evoked forepaw treading }\end{array}$ & [74] \\
\hline $\begin{array}{l}\text { LY487379 } \\
\text { LY379268 }\end{array}$ & PCP- and AMPH-induced model & $\begin{array}{l}\text { LY487379 and LY379268 induced dose-dependent reductions in PCP- and } \\
\text { AMPH-induced hyperlocomotor activity. LY487379 reversed } \\
\text { AMPH-induced disruption of prepulse inhibition of the acoustic startle } \\
\text { reflex. LY379268 when administered chronically failed to block AMPH- } \\
\text { and PCP-induced hyperlocomotor activity. }\end{array}$ & [75] \\
\hline LY354740 & PCP-induced psychosis & $\begin{array}{l}\text { LY354740 induced anxiolytic-like effects and attenuated PCP-induced } \\
\text { hyperlocomotion. It did not modify PCP-induced working memory } \\
\text { deficits and had no effect on PCP-evoked amnesia. }\end{array}$ & [76] \\
\hline LY354740 & PCP- and AMPH-induced model & $\begin{array}{l}\text { LY354740 moderated effects of PCP on prepulse inhibition of } \\
\text { acoustic startle }\end{array}$ & [77] \\
\hline $\begin{array}{l}\text { LY354740 } \\
\text { LY487379 }\end{array}$ & PCP-induced psychosis & $\begin{array}{l}\text { Acute pretreatment with LY354740 or LY487379 facilitated social } \\
\text { discrimination in rats with PCP administration history without affecting } \\
\text { total time spent in social interaction }\end{array}$ & [78] \\
\hline LY379268 & PCP- and MK-801-induced model & $\begin{array}{c}\text { LY379268 blocked PCP- and MK-801-induced hyperlocomotion in } \\
\text { dopamine-deficient and control mice }\end{array}$ & [79] \\
\hline $\begin{array}{l}\text { LY354750 } \\
\text { LY544344 }\end{array}$ & PCP-induced model & LY544344 but not LY354740 inhibited PCP-induced hyperlocomotion. & [80] \\
\hline LY379268 & Ketamine-induced model & $\begin{array}{l}\text { LY379268 reduced ketamine-evoked hyperlocomotion but it failed to } \\
\text { restore prepulse inhibition deficits. Low dose }(1 \mathrm{mg} / \mathrm{kg}) \text { produced } \\
\text { anxiolytic effects whereas a higher dose }(3 \mathrm{mg} / \mathrm{kg}) \text { appeared to } \\
\text { be anxiogenic. }\end{array}$ & [81] \\
\hline LY379268 & MK-801-induced model & $\begin{array}{l}\text { LY379268 recovered the disrupted NMDA receptor expression induced by } \\
\text { MK-801, enhanced NMDA-induced current in prefrontal neurons and } \\
\text { reversed MK-801-induced NMDA receptor dysfunction via } \\
\text { Akt/GSK-3 } \beta \text { signaling. }\end{array}$ & [82] \\
\hline LY379268 & Ketamine-induced model & $\begin{array}{l}\text { Pretreatment with either systemic or local LY379268 blocked } \\
\text { ketamine-induced glutamate, but no dopamine release in the mPFC. } \\
\text { Systemic but not local administration blocked the effect of NMDA on } \\
\text { evoking glutamate release. }\end{array}$ & [65] \\
\hline $\begin{array}{l}\text { LY379268 } \\
\text { LY341495 }\end{array}$ & PCP- and LSD-induced model & $\begin{array}{c}\text { LY341495 potentiated LSD-induced stimulus control, which was } \\
\text { diminished in the presence of LY379268. In PCP-trained rats, LY341495 } \\
\text { has no effect on stimulus control by an intermediate dose of PCP. } \\
\text { In contrast, the training dose of PCP was significantly but incompletely } \\
\text { antagonized by LY379268. }\end{array}$ & [83] \\
\hline LY379268 & Ketamine-induced model & $\begin{array}{l}\text { LY379268 reversed ketamine-induced hyperactivity and inhibited } \\
\text { ketamine-evoked norepinephrine release in the ventral hippocampus. }\end{array}$ & [84] \\
\hline LY379268 & PCP-induced model & LY379268 blocked PCP-evoked ambulatory activity and fine movements. & [85] \\
\hline LY379268 & $\begin{array}{l}\text { two-hit model (PCP-induced on } \\
\text { the background of neuregulin } \\
1 \text { mutation) }\end{array}$ & $\begin{array}{l}\text { PCP significantly reduced NMDA receptor and GABAA receptor binding } \\
\text { density in the prefrontal cortex, hippocampus, and nucleus accumbens } \\
\text { while LY379268 restored NMDA and GABAA receptors level }\end{array}$ & [86] \\
\hline LY379268 & MK-801-induced model & $\begin{array}{c}\text { LY379268 failed to improve MK-801-induced impairments in working } \\
\text { memory. LY379268 augmented MK-801 potentiated gamma and high } \\
\text { gamma oscillations but did not affect auditory-evoked gamma oscillation } \\
\text { deficits caused by MK-801. }\end{array}$ & [87] \\
\hline
\end{tabular}

The early report showed that administration of LY354740, a prototypical drug interacting with both mGluR2 and mGluR3, was effective in attenuation of deficits in working memory, locomotion and excessive glutamatergic signaling in PCP-induced model 
of NMDA receptor hypofunction [62]. In the same model, another mGluR2/3 agonist LY379268 reversed certain behavioral phenotypes and prepulse inhibition [74] to a degree comparable with atypical antipsychotic clozapine. Further studies on mGluR3 and mGluR2 knockout mice demonstrated that mGluR2, but not mGluR3, mediated the effects of LY379268 in experimental models predictive of antipsychotic activity [71]. LY379268 also showed promising effects in other schizophrenia models based on pharmacological blockage of NMDA receptor (ketamine and MK-801) [87] but had a marginal effect on amphetamine (AMPH)-induced hyperlocomotion in rats [72]. These results demonstrate the specificity of mGluR2/3 agonists toward glutamatergic signaling without any effects on the dopamine system.

Despite some conflicting results, recent studies supported the positive effects of mGluR2/3 stimulation on cognitive and negative symptoms of schizophrenia. LY379268 was found to be successful in reversing post-weaning social isolation-induced recognition memory deficits [88] and prenatal stress-induced schizophrenia-like neurochemical and behavioral changes. The latter is likely to be caused by increased expression of growth arrest and DNA damage $45-\beta$ (Gadd45- $\beta$ ) protein and subsequent epigenetic modifications. Increased binding of Gadd45- $\beta$ to the promoter regions of reelin, BDNF, and GAD67 was also detected upon treatment with LY379268 [89], suggesting a putative underlying mechanism. Interestingly, Holloway and colleagues, using a model of variable and unpredictable stress in mice, showed decreased mGluR2-dependent antipsychotic-like effect of LY379268 in mice born to stressed mothers during pregnancy [90]. These data support the hypothesis of an early developmental origin of schizophrenia and indicate that modulation of mGluR2/3 may impact the epigenetic process in the early phase of this disease.

These studies' critical question is whether early stage treatment can rescue cognitive defects and confer benefits for schizophrenia behavior in adulthood. Using neurodevelopment schizophrenia model, Xing and coworkers has recently reported that LY379268 can improve learning deficits in juvenile rats via a mechanism dependent on inhibition of glycogen synthase kinase-3 $\beta$ (GSK3 $\beta$ ) [91]. Moreover, the drug affected neither excitability in the prefrontal cortex nor glutamatergic signaling but prevented dendritic spine loss in adults. Similarly, juvenile treatment with a subchronic dose of a novel mGLuR2 agonist/mGluR3 antagonist LY395756 alleviated the learning deficits and cognitive flexibility impairments in adults [92].

Studies on long-term administration and dose-dependent effects of mGluR2/3 agonists in normal and disease conditions are scarce. An early report suggested that LY379268 dose-dependent reduction in hyperlocomotion in PCP and AMPH-induced models of schizophrenia is not reproduced during chronic treatment [75]. In the drug abuse model, consecutive administration of LY379268 decreased toluene-induced hyperactivity [93] while it did not affect PCP-evoked hyperlocomotion when repeatedly dosed [94]. Subchronic treatment with LY354740 also failed to reverse ketamine-induced hyperlocomotion and prepulse inhibition deficits [95]. Comparison of short versus long-term (2 days vs. 14 days) LY379268 effects revealed a significant reduction in mGluR2 expression in the hippocampus, nucleus accumbens, caudate and ventral pallium as well as increased pERK/ERK ratio during 14-day drug administration [96]. The authors also observed increasing immunoreactivity of CREB protein across all brain regions, which may suggest the activation of multiply compensatory mechanisms in response to drug's chronic systemic administration.

Subsequently, several other drugs have been developed. A prototypical mGluR2/3 PAM - LY487379 promoted cognitive flexibility, facilitated behavioral inhibition [97], and reversed social discrimination deficits induced by neonatal PCP treatment [78]. These effects were accompanied by enhanced extracellular serotonin and norepinephrine levels in the prefrontal cortex. Social recognition impairments elicited by MK-801 were also amended by LY379268 and mGluR2 PAMs - biphenyl indanone A (BINA) and TASP0443294 [41]. Since the effect of BINA on social memory was blocked by mGluR2/3 antagonist LY341495 [98], the positive effects of mGluR2/3 agonists seem to be mediated by mGluR2. BINA also modulated excitatory neurotransmission in $\mathrm{MPFC}$ as well as attenuated the effects of in vivo activation of 
5-HT2A receptor and serotonin-induced increases in spontaneous excitatory postsynaptic currents in mPFC [99]. Like TASP0443294, other mGluR2 PAMs-JNJ-40411813 and ADX71149 inhibited PCP-induced hyperlocomotion but did not affect AMPH-elicited hyperactivity [100]. Recently, novel mGluR2 PAM-SAR218645 reduced head twitch behavior in several models of schizophrenia positive symptoms but was ineffective in prevention of hyperactivity in pharmacological and transgenic models [101]. However, in cognitive symptoms models, it improved MK-801-induced episodic memory deficits and reversed working memory impairments in NMDA receptor-deficient $\left(\mathrm{Nr} 1^{\text {neo-/- }}\right)$ mice, thus providing a piece of convincing evidence for mGluR2 PAMs cognition-enhancing effects in the genetic model of schizophrenia.

Given that antipsychotic drugs are administered chronically, it is unknown whether the acute effects of novel substances reported in animal studies will also be seen in clinical practice or their long-term use will result in tolerance. Furthermore, it must be considered that mGluR2/3 agonists, although successfully reversing some cognitive effects in NMDA receptor hypofunction models $[63,87,88]$, have no effect or impair cognition in healthy animals [76]. This implies that the therapeutic use of mGluR2/3 agonists may be limited to the conditions of NMDA receptor dysfunction or have difference efficacy depends on the disease state.

\subsubsection{Clinical Trials}

The first drug targeting mGluR2/3 receptors that has been clinically tested in human for the treatment of schizophrenia was LY-2140023, as it was suspected that it might normalize hyperactive cortical pyramidal neurons in the thalamus, prefrontal cortex and limbic system [102]. The first run of randomized phase II clinical trial demonstrated that $40 \mathrm{mg}$ LY-2140023 taken twice daily improved both positive and negative, but not cognitive, symptoms of schizophrenia, as measured with PANSS (Positive and Negative Syndrome Scale) and CGI-S (Clinical Global Impression Scale) when compared to placebo. However, no significant difference was seen between tested group and olanzapine positive group. A second randomized, double-blind clinical trial showed no differences between various LY-2140023 doses (5, 20, 40, $80 \mathrm{mg}$ ) and placebo on PANSS total score [103]. In 2013, another phase II, randomized, parallel, active-controlled study was performed to investigate efficacy and long-term side effects of LY-2140023 administration [104]. Over the first 6-8 weeks of treatment, no significant difference was seen between LY-2140023 and olanzapine, risperidone, or aripiprazole groups, but at later time points, the effectiveness of antipsychotic medications was higher than LY-2140023. As no primary endpoint was met, the Eli Lilly company that developed the drug ceased their ongoing studies of phase III. The possible causes of failure were discussed by Li and colleagues in [105].

Addex Company announced that its newest mGluR2 PAM, ADX71149 demonstrated safety and tolerance in healthy men and women, and it passed IIa of clinical trial being efficient in patients with negative schizophrenia symptoms [106,107]. The drug at a dose of $150 \mathrm{mg}$ administered twice daily for 7 days significantly ameliorated smoking withdrawalevoked deficits in attention and episodic memory compared to placebo. At a higher dose (500 mg), ADX71149 reduced S(+) ketamine-induced negative symptoms and improved the total score of BPRS (Brief Psychiatric Rating Score) [107]. Despite these promising results, as of 2021, the results of phase III have not been disclosed to public.

In 2016, AstraZeneca released the phase II outcome on efficacy and safety of AZD8529, a selective PAM at the mGluR2 in symptomatic patients with schizophrenia [108]. There were no differences in PANSS total, negative, and positive symptoms subscale and CGI-S scores between patients in treated versus placebo groups. In early 2020, randomized, placebocontrolled, double-blind, and multisite study led by J. Lieberman re-investigated the clinical efficacy of pomaglumetad (POMA, LY-404,039) and TS-134 using blood oxygen leveldependent response [109]. Treatment with high-dose of POMA (320 mg/d for 10 days) significantly reduced ketamine-induced BPRS total symptoms but did not affect target engagement [110]. In contrast, TS-134 administered at a $20 \mathrm{mg} /$ day dose for 6 days demonstrated both symptom reduction and target engagement. 
Despite the progress that has been made in recent years, the mechanisms of mGluR2/3 action are still not elucidated, leaving the questions about effectiveness and safe window for mGluR2/3 agonist treatment unanswered. However, given the tolerance and low adverse effects, selective mGluR2/3 PAMs and agonists should still be considered promising drugs in schizophrenia treatment alone or in combination with other antipsychotics.

\subsubsection{Advantages and Disadvantages of Clinical Use of mGluR2/3 Agonists}

It has been widely documented that typical antipsychotics may be associated with higher risk of extrapyramidal symptoms (EPS), whereas the use of atypical antipsychotics can results in higher risk of metabolic syndrome [111,112]. Clinical trials for mGluR2/3 agonists showed neglectable spectrum of side effects commonly seen for antipsychotics targeting dopaminergic system. LY2140023, for instance, was generally well tolerated, produced no changes in electroencephalogram and did not increase the treatment-emergent adverse events (TEAEs) [113]. Moreover, there were no withdrawal effects after 4-week drug administration [114]. The safety, tolerability, and potential side effects of ADX71149 in patients with schizophrenia were also a subject of clinical investigation. The aforementioned preliminary results of Phase IIa demonstrated a trend toward separation from placebo after 1 month of treatment when the drug was used as an adjunct to antipsychotics, thus suggesting a potential for ameliorating of negative symptoms [115].

Although no severe side effects were observed, the efficiency of mGluR2/3 agonists used as a monotherapy in schizophrenia turned out to be comparable to currently used antipsychotics. In a phase II comparative safety study, LY2140023 did not bring any statistically significant improvement over olanzapine, risperidone or aripiprazole in terms of positive or negative symptoms [104]. The initial improvement in PANSS total score as well as the incidence of serious adverse effects were also comparable between groups. In 24-week randomized, double-blind study, LY2140023 demonstrated lower improvement in PANSS total score and higher incidence of serious adverse effects compared to aripiprazole and lack of significant changes in the incidence of TEAEs and suicidal behavior [116]. Despite these disappointing results of mGluR2/3 agonists as a monotherapy, the drugs may still have potential as an adjunct therapy to currently used antipsychotics [115].

\section{Group III mGluRs}

\subsection{General Characteristics}

Group III of metabotropic glutamate receptors is the most extensive family consisting of mGluR4, mGluR6, mGluR7 and mGluR8 subtypes. Similar to group II, these receptors signal via $G \alpha_{i / o}$ to inhibit adenylyl cyclase [15] and module the activity of several downstream signaling pathways, including MAPK and PI3-kinase [17]. Activation of mGluRs of group III can regulate neurotransmitter secretion by acting on several ion channels or through $\mathrm{G}_{\beta \gamma}$-dependent inhibition of vesicular fusion [117]. Their contribution to the induction of two forms of short-term synaptic plasticities: paired-pulse facilitation and post-tetanic potentiation, has also been demonstrated [118,119]. The function of mGluR6 will not be discussed here due to its restricted expression in retinal ON bipolar cells, in which it amplifies visual transmission [120].

\section{2. $m$ GluR4}

mGluR4 is expressed in the cerebellar cortex, basal ganglia, thalamus, and hippocampus, predominantly in the presynaptic active zones. In the cerebellar cortex and hippocampus, mGluR4 localizes to the terminals forming type I synapses, while in basal ganglia its location is mostly in type II synapses in dendritic shafts. In the hippocampus, mGluR4 labeling was predominant in the dentate molecular layer and CA1-3 stratum lacunose molecular [121]. Still little is known about the presynaptic mechanisms of mGluR4. The most compelling physiological function evidence has been demonstrated at the glutamatergic synapses between parallel fibers and Purkinje cells. Activation of mGLuR4 at these synapses was exclusively responsible for the depression of parallel fiber-Purkinje cells 
excitatory transmission and inhibition of presynaptic $\mathrm{Ca}^{2+}$ entry $[122,123]$. The mGluR4 receptors are also expressed in GABAergic and glutamatergic synapses in brain regions involved in acoustic startle function. As startle reactivity is modulated by cortico-striatopallido-pontine circuity [124], it is hypothesized that glutamate release from the auditory afferents may be inhibited by the presynaptically located group III mGluRs. Alterations in the presynaptic release of GABA and/or glutamate, especially in the hippocampus and basal ganglia, may account for decreased acoustic startle response and prepulse inhibition in mGluR4 ${ }^{-/-}$mice [125]. A much more significant increase in glutamate levels was observed in the caudate nucleus, which receives extensive glutamatergic innervation from the cerebral cortex, of mGluR4 $4^{-/-}$mice stimulated with NMDA [126]. Since the activation of mGluR4 reduces glutamatergic transmission in the hippocampus [127], prepulse inhibition and acoustic startle response deficits resulted from mGluR4 knockout may be associated with NMDA receptor activity. Disrupted prepulse inhibition and acoustic startle response have been found in various neuropsychiatric diseases, including schizophrenia [128,129].

\section{Targeting mGluR4 in Preclinical Models of Schizophrenia}

Investigation the utility of individual representatives of group III mGluRs in schizophrenia treatment became possible since the discoveries of blood brain barrier permeable selective ligands suitable for in vivo studies (Table 4). This enabled the first reports on the antipsychotic activity of LSP1-2111 and LSP4-2022, which behaved as preferential orthosteric agonists of mGluR4 [130]. These compounds showed improved selectivity, as their affinity for mGluR4 was 30- and 300-fold higher than for mGluR8, respectively. LSP12111 reversed amphetamine- and MK-801-induced hyperlocomotion as well as DOI (2,5dimethoxy-4-iodoamphetamine)-induced head twitches [131]. The efficacy of LSP1-2111 was also demonstrated in various preclinical models of cognitive and negative schizophrenia symptoms including object recognition and social interaction tests [132]. Similarly, LSP42022 has been shown to attenuate MK-801-evoked neurotransmitter release and possess antipsychotic-like activity, which was abolished by pharmacological blockers of 5-HT1A receptors [133]. Further studies revealed that LSP4-2022 administered at subthreshold dose produced antipsychotic effects acting synergistically with 5-HT1A receptor agonist-8hydroxy-dipropylaminotetraline and agonists of GABAB receptors [134]. A robust antipsychotic effect was also seen when LSP4-2022 was administered together with M4 muscarinic receptor PAM-VU152100. One of the results of this combination was a reduction of 5HT2A-dependent spontaneous excitatory postsynaptic currents in the prefrontal cortex, suggesting cooperative action of mGluR4 and M4 receptors in glutamate release [135].

Similar promise in alleviating of all three symptom clusters of schizophrenia was provided by mGluR4-selective PAMs-LuAF21934, LuAF32615 and ADX88178. In behavioral tests modeling positive, negative, and cognitive symptoms, these compounds displayed antipsychotic action, albeit with different efficiency. LuAF21934 and LuAF32615 reversed MK-801- and amphetamine- induced hyperactivity in a dose-dependent manner [136]. Furthermore, both compounds inhibited DOI-induced head twitches and normalized increased frequency of spontaneous excitatory of postsynaptic currents in brain slices. However, Lu AF21934 was unable to antagonize DOI-induced behavioral deficits in mGluR4 ${ }^{-/-}$mice. Both tested drugs reversed deficits in social interactions and were active in the delay spatial alternation test, thus providing a support for a potential utility of pharmacological targeting of mGluR4. ADX88178 was effective in reduction of MK-801-induced hyperlocomotion and DOI-evoked head twitches but did not show any effects in conditioned avoidance response test in rats [137].

Recently, Fazio and colleagues showed that cinnabarinic acid, a metabolite of kynurenine pathway of tryptophan metabolism, acts at low doses as a partial agonist of mGluR4, with no activity at other mGlu receptor subtypes [138]. Systemic treatment with a dose $<1 \mathrm{mg} / \mathrm{kg}$ attenuated MK-801-evoked glutamate release and hyperlocomotion [139]. Cinnabarinic acid also demonstrated a dose-dependent effect in several behavioral tests used to score antipsychotic activity, but inhibited excitatory synaptic transmission and no longer exerted 
antipsychotic activity in mGluR4 ${ }^{-/-}$mice. Interestingly, the level of cinnabarinic acid was significantly reduced in the prefrontal cortex of schizophrenia individuals [139].

Table 4. Summary of the preclinical studies on Group III receptor ligands.

\begin{tabular}{|c|c|c|c|c|}
\hline Target & Tested Drug & Animal Model & Results & References \\
\hline \multirow{6}{*}{ mGluR4 } & $\begin{array}{l}\text { LSP1-2111 } \\
\text { LSP4-2022 }\end{array}$ & $\begin{array}{l}\text { MK-801-induced model } \\
\text { AMPH-induced model }\end{array}$ & $\begin{array}{l}\text { Reversed AMPH- and MK-801-induced } \\
\text { hyperlocomotion }\end{array}$ & {$[131,134]$} \\
\hline & $\begin{array}{l}\text { LSP1-2111 } \\
\text { LSP4-2022 }\end{array}$ & $\begin{array}{l}\text { DOI-induced model of } \\
\text { hallucinations }\end{array}$ & $\begin{array}{c}\text { Antagonized } \\
\text { DOI-induced head twitches }\end{array}$ & {$[131,134]$} \\
\hline & $\begin{array}{l}\text { LuAF21934 } \\
\text { LuAF32615 }\end{array}$ & $\begin{array}{l}\text { MK-801-induced model } \\
\text { AMPH-induced model }\end{array}$ & $\begin{array}{l}\text { Both compounds antagonized AMPH- } \\
\text { and MK-801-induced hyperlocomotion }\end{array}$ & [136] \\
\hline & $\begin{array}{l}\text { LuAF21934 } \\
\text { LuAF32615 }\end{array}$ & $\begin{array}{l}\text { DOI-induced model of } \\
\text { hallucinations }\end{array}$ & $\begin{array}{c}\text { Inhibited DOI-induced head twitches. } \\
\text { Lu AF21934 was ineffective in } \\
\text { mGluR4 }{ }^{-/-} \text {mice }\end{array}$ & [136] \\
\hline & ADX88178 & $\begin{array}{l}\text { MK-801-induced model } \\
\text { DOI-induced model of } \\
\text { hallucinations }\end{array}$ & $\begin{array}{l}\text { ADX88178 reduced MK-801-induced } \\
\text { hyperlocomotion and DOI-evoked head } \\
\text { twitches but had no effect in } \\
\text { conditioned avoidance response test }\end{array}$ & [137] \\
\hline & Cinnabarinic acid & MK-801-induced model & $\begin{array}{l}\text { Reduced MK-801-induced glutamate } \\
\text { release and hyperlocomotion }\end{array}$ & [139] \\
\hline \multirow{4}{*}{ mGluR7 } & AMN082 & $\begin{array}{l}\text { MK-801-induced model } \\
\text { AMPH-induced model }\end{array}$ & $\begin{array}{c}\text { AMN082 did not influence } \\
\text { AMPH-induced hyperlocomotion but } \\
\text { enhanced MK-801-induced } \\
\text { hyperactivity }\end{array}$ & [131] \\
\hline & AMN082 & $\begin{array}{l}\text { DOI-induced model of } \\
\text { hallucinations }\end{array}$ & $\begin{array}{c}\text { Increased number of the DOI-induced } \\
\text { head twitches }\end{array}$ & [131] \\
\hline & $\begin{array}{c}\text { MMPIP } \\
\text { ADX71743 }\end{array}$ & MK-801-induced model & $\begin{array}{l}\text { Both drugs inhibited MK-801-induced } \\
\text { hyperactivity, reversed MK-801-induced } \\
\text { disturbances in novel object recognition, } \\
\text { prepulse inhibition and spatial } \\
\text { delayed alternation }\end{array}$ & [140] \\
\hline & $\begin{array}{l}\text { MMPIP } \\
\text { ADX71743 }\end{array}$ & $\begin{array}{l}\text { DOI-induced model of } \\
\text { hallucinations }\end{array}$ & Inhibited DOI-induced head twitches & [140] \\
\hline mGluR8 & DCPG & $\begin{array}{l}\text { PCP-induced model } \\
\text { AMPH-induced model }\end{array}$ & $\begin{array}{l}\text { Decreased amphetamine but not } \\
\text { PCP-induced hyperactivity }\end{array}$ & [141] \\
\hline
\end{tabular}

\section{3. $m G l u R 7$}

The mGluR7 is highly expressed in brain regions responsible for emotion, cognition, and reward, hence in the hippocampus, amygdala, dorsal striatum, nucleus accumbens, amygdala, locus coeruleus, olfactory bulbs and ventral tegmental area [142]. Presynaptically localized mGluR7s acting as autoreceptors are mainly involved in regulating glutamate secretion, while those functioning as heteroreceptors regulate GABA release and possibly other monoamines $[143,144]$. Because these receptors are immobilized at presynaptic active zones of both excitatory and inhibitory synapses, they play a critical role in shaping synaptic response for GABAergic and glutamatergic neurotransmission $[145,146]$. Compared to other group III receptors, mGluR7 has a low affinity for glutamate; therefore it can be activated only by sufficiently high levels of extracellular glutamate [147]. For that reason, it is assumed that mGluR7 is activated only during intense, high-frequency synaptic stimulation. On the other hand, the newest results suggest that mGluR7 may be constitutively active and that activity can be sustained by the interaction with postsynapic adhesion molecule Elfn2 at the excitatory synapses [148,149]. Mice lacking mGluR7 demonstrated deficits in short-term neural plasticity in the hippocampus and some impairments in memory and learning [150]. Recent studies also showed that mGluR7 $7^{-/-}$mice displayed 
extinction of a conditioned fear response [151] and reduced shock-induced freezing [152], which are amygdala-dependent paradigms. Moreover, mice exhibited reduced anxiety-like responses consistent with mGluR7 role in emotional disorders [153]. Recently, Tassin and coworkers showed that inactivation of this receptor modulated the global thalamic excitability, decreasing its propensity to switch from tonic to oscillatory mode [154]. Therefore, mGluR7-dependent reduction in thalamocortical neurotransmission, a circuit suggested to be overactive in schizophrenia, may be a goal for new therapies of this disease.

Targeting mGluR7 in Preclinical Models of Schizophrenia

The first selective mGluR7 agonist-AMN082 was discovered in 2005 using a random high-throughput screening of chemical libraries [155] (Table 4). A few years later, Wieronska and colleagues demonstrated that it had no effect on amphetamine-induced hyperlocomotion, but rather it produced an enhancement in MK-801-induced hyperactivity [131]. Using a behavioral model of hallucinations, the same authors showed increased DOI-induced head twitches. In this experiment, hallucinogenic-like activity was achieved by administering the 5-HT2A receptor agonist DOI, which is known to provoke a characteristic behavior of twitches of heads in mice [156]. AMN082-potentiated hyperlocomotion and head twitches were absent in mGluR7 $7^{-/-}$mice [131], suggesting that mGluR7 mediated them. These results provided evidence for lack of antipsychotic activity and instead showed the pro-psychotic action of AMN082 in preclinical models. However, several studies suggested more complex activity of this drug with the observable effects detected in some systems but not in others [146]. Therefore, the negative findings with AMN082 in the pharmacological animal models of schizophrenia should be interpreted with caution.

So far, only two mGluR7 NAMs-MMPIP and ADX71743 have been tested in schizophrenia models [157,158]. Cieslik and coworkers used MK-801-induced hyperactivity and DOIinduced head twitches to test both drugs' efficacy in the amelioration of positive symptoms of schizophrenia [140]. MMPIP and ADX71743 reversed MK-801-induced deficits; however, ADX71743 was effective at lower doses $(5 \mathrm{mg} / \mathrm{kg}$ ), while MMPIP was active only at the highest administered dose $(15 \mathrm{mg} / \mathrm{kg})$. This contrasts with the previous study showing only a small reduction in amphetamine-induced hyperactivity by ADX71743, and much higher doses $(100$ and $150 \mathrm{mg} / \mathrm{kg}$ ) were necessary to observe a statistically significant effect [158] Both drugs also reversed DOI-induced head twitches. Again, the activity of ADX71743 was observed at doses lower than that for MMPIP $(2.5 \mathrm{mg} / \mathrm{kg}$ and higher vs. $5 \mathrm{mg} / \mathrm{kg}$ and higher $)$ In the study of Kalinichev, ADX71743 was active at the dose of $100 \mathrm{mg} / \mathrm{kg}$ and higher [158]. Both drugs were also active when tested in models of cognition, attentional deficits and negative symptoms of schizophrenia [140]. Several other drugs targeting mGluR7 have been synthesized recently, for instance VU6010608 (2017) or VU6027459 (2020), but their utility in schizophrenia treatment has not been investigated yet.

\section{4. $m$ GluR8}

The mGluR8 was cloned as the last receptor in the mGluR family [159]. It is widely expressed throughout the CNS, especially in the olfactory bulb, lateral reticular nucleus of the thalamus, cerebral cortex, cerebellum, hippocampus and retina [160]. Immunochemical studies demonstrated that mGluR8 is located in the terminal fields of the lateral perforant path in the outer molecular layer of the dentate gyrus and the CA3 stratum lacunosum. However, its highest level was observed in the caudate nucleus and putamen, the critical brain regions linked with schizophrenia. Electrophysiological studies using selective agonists suggest that mGluR8 may function as a presynaptically localized autoreceptor gating synaptic transmission into the hippocampus [161]. Therefore, the receptor may be activated only by high concentrations of released glutamate. In such circumstances, mGluR8 may provide negative feedback for glutamate synthesis, packaging and/or release from synaptic boutons [161,162].

By analyzing mGluR8 null mutant mice's performance, Gerlai and coworkers demonstrated subtle behavioral alterations involving novelty-induced hyperactivity and delayed 
response to certain stimuli [163]. By contrast, Goddyn and colleagues did not find any deficits in neuromotor performance, prepulse inhibition, social exploration, learning and memory in mGluR8 ${ }^{-/-}$mice compared to wild type [125]. Although the behavioral effects of mGluR8 knockout may be inconclusive, there is an agreement on its function in controlling body weight $[126,164,165]$. The $\mathrm{mGluR}^{-/-}$mice have also been shown to demonstrate anxiety phenotype $[160,166]$. However, some newest studies failed to reproduce this finding $[164,165]$. Despite these discrepancies, the role of mGluR8 in memory and learning suggests that modulation of its activity by specific agonists/antagonists may be beneficial for the treatment of cognitive alterations in schizophrenia.

\section{Targeting mGluR8 in Preclinical Models of Schizophrenia}

Several mGluR8 ligands have been identified, and their antipsychotic properties have been tested in various animal models (Table 4). (R,S)-4-Phosphophenylglycine (PPG), a selective agonist of group III mGluRs with 10-fold higher affinity for mGluR8 than for mGLuR4, 6, 7 [167] depressed field excitatory postsynapic potentials (fEPSP) of the lateral entorhinal cortex to hippocampal granule cell projection [168] and significantly reduced neurotransmitter release without affecting presynaptic $\mathrm{Ca}^{2+}$ entry. Interestingly, PGG was also able to act as an inverse agonist at mGluR7 [169]. Another phenylglycine derivative, (S)-3,4-dicarboxyphenylglycine (DCPG), with the selectivity for mGLuR8 100-fold higher than for other groups' III members, decreased amphetamine but not PCP-induced hyperactivity, but at this dose $(2.5 \mathrm{mg} / \mathrm{kg})$ did not affect spontaneous locomotor activity [141]. This contrasts with other studies showing significant reversal of amphetamine-induced locomotor activity; however, the discrepancy may arise from dose-dependent inhibition of spontaneous locomotor activity by the drug, thus producing confounding interpre-

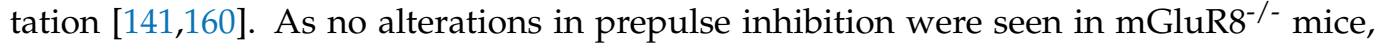
it may be possible that mGluR8 is not directly engaged in schizophrenia neuropathology. On the other hand, its role in hippocampal neurotransmission suggests that it may still be a promising target for novel antipsychotic with cognitive-enhancing properties. This is undoubtedly tempting but also requires experimental verification.

\section{Concluding Remarks}

A strong line of evidence from the preclinical studies indicates that representatives of all three groups of mGluRs should be considered when designing novel therapeutical strategies in schizophrenia treatment. The distribution of mGluR subtypes in brain regions traditionally linked with schizophrenia deficits, their modulatory action on other disease-associated receptors such as NMDA, AMPA or GABA(A) as well as the efficacy of their agonists or PAMs provide a strong foundation for considering mGluRs as potential targets for new generation antipsychotics. The research on animal models of schizophrenia demonstrated a crosstalk between various mGluRs ligands and dopaminergic, serotonergic, and glutamatergic pathways, thus revealing their potential to become effective alternative or improvement for the drugs currently used in clinical practice. This review has some limitations that should be acknowledged. First, it mostly covers preclinical findings due to limited availability regarding the efficiency of potential drugs in human studies. Second, whenever possible, we attempted to present the results of clinical trials, which sometimes led to confounding results due to lack of sample representativeness and inappropriate cohort selection. Third, the exact mechanism of potential mGluR-based novel antipsychotics is unknown, so the discussion about the molecular changes downstream particular mGluRs is frequently speculative. Lastly, the neuropharmacology of schizophrenia is rapidly changing, so although we tried to present the progress in the field by covering the majority of recently published papers, some of them could be omitted due to space restrictions. Even despite these limitations, the existing literature strongly supports further investigations into targeting mGluRs in schizophrenia. However, extensive research into how to translate preclinical results into clinically effective strategies is needed. 
Author Contributions: T.B. and W.K. individually contributed to manuscript writing, tables preparation, manuscript check and preparation of its final version. Both authors have read and agreed to the published version of the manuscript.

Funding: This work was supported by National Science Centre grant no. 2019/33/B/NZ4/00587 and by Medical University of Lodz grant no. 503/6-086-02/503-61-001.

Conflicts of Interest: The authors declare no conflict of interest. The funders had no role in the design of the study; in the collection, analyses, or interpretation of data; in the writing of the manuscript, or in the decision to publish the results.

\section{References}

1. Charlson, F.J.; Ferrari, A.J.; Santomauro, D.F.; Diminic, S.; Stockings, E.; Scott, J.G.; McGrath, J.J.; Whiteford, H.A. Global Epidemiology and Burden of Schizophrenia: Findings from the Global Burden of Disease Study 2016. Schizophr. Bull. 2018, 44, 1195-1203. (In English) [CrossRef] [PubMed]

2. Keefe, R.S.; Eesley, C.E.; Poe, M.P. Defining a cognitive function decrement in schizophrenia. Biol. Psychiatry $2005,57,688-691$. (In English) [CrossRef] [PubMed]

3. Lally, J.; MacCabe, J.H. Antipsychotic medication in schizophrenia: A review. Br. Med. Bull. 2015, 114, 169-179. (In English) [CrossRef]

4. Huhn, M.; Nikolakopoulou, A.; Schneider-Thoma, J.; Krause, M.; Samara, M.; Peter, N.; Arndt, T.; Bäckers, L.; Rothe, P.; Cipriani, A.; et al. Comparative efficacy and tolerability of 32 oral antipsychotics for the acute treatment of adults with multiepisode schizophrenia: A systematic review and network meta-analysis. Lancet 2019, 394, 939-951. (In English) [CrossRef]

5. Chong, J.W.X.; Tan, E.H.-J.; Chong, C.E.; Ng, Y.; Wijesinghe, R. Atypical antipsychotics: A review on the prevalence, monitoring, and management of their metabolic and cardiovascular side effects. Ment. Health Clin. 2016, 6, 178-184. (In English) [CrossRef] [PubMed]

6. Zhou, Y.; Danbolt, N.C. Glutamate as a neurotransmitter in the healthy brain. J. Neural Transm. 2014, 121, 799-817. (In English) [CrossRef] [PubMed]

7. Farber, N.B. The NMDA receptor hypofunction model of psychosis. Ann. N. Y. Acad. Sci. 2003, 1003, 119-130. (In English) [CrossRef] [PubMed]

8. Cadinu, D.; Grayson, B.; Podda, G.; Harte, M.K.; Doostdar, N.; Neill, J.C. NMDA receptor antagonist rodent models for cognition in schizophrenia and identification of novel drug treatments, an update. Neuropharmacology 2018, 142, 41-62. (In English) [CrossRef]

9. Adell, A. Brain NMDA Receptors in Schizophrenia and Depression. Biomolecules 2020, 10, 947. (In English) [CrossRef]

10. Goff, D. The Therapeutic Role of d-Cycloserine in Schizophrenia. Adv. Pharmacol. 2016, 76, 39-66. (In English) [CrossRef]

11. MacKay, M.B.; Kravtsenyuk, M.; Thomas, R.; Mitchell, N.D.; Dursun, S.M.; Baker, G.B. D-Serine: Potential Therapeutic Agent and/or Biomarker in Schizophrenia and Depression? Front. Psychiatry 2019, 10, 25. (In English) [CrossRef] [PubMed]

12. Ebrahimi-Ghiri, M.; Khakpai, F.; Zarrindast, M.R. Combined treatment of scopolamine and group III mGluR antagonist, CPPG, exerts antidepressant activity without affecting anxiety-related behaviors. Physiol. Behav. 2020, 224, 113034. (In English) [CrossRef] [PubMed]

13. Chaki, S. mGlu2/3 receptor antagonists. Adv. Pharmacol. 2019, 86, 97-120. [CrossRef]

14. Kim, J.H.; Marton, J.; Ametamey, S.M.; Cumming, P. A Review of Molecular Imaging of Glutamate Receptors. Molecules 2020, 25, 4749. (In English) [CrossRef]

15. Niswender, C.M.; Conn, P.J. Metabotropic glutamate receptors: Physiology, pharmacology, and disease. Annu. Rev. Pharmacol. Toxicol. 2010, 50, 295-322. (In English) [CrossRef] [PubMed]

16. Mazzitelli, M.; Palazzo, E.; Maione, S.; Neugebauer, V. Group II Metabotropic Glutamate Receptors: Role in Pain Mechanisms and Pain Modulation. Front. Mol. Neurosci. 2018, 11, 383. [CrossRef] [PubMed]

17. Iacovelli, L.; Bruno, V.; Salvatore, L.; Melchiorri, D.; Gradini, R.; Caricasole, A.; Barletta, E.; De Blasi, A.; Nicoletti, F. Native group-III metabotropic glutamate receptors are coupled to the mitogen-activated protein kinase/phosphatidylinositol-3-kinase pathways. J. Neurochem. 2002, 82, 216-223. (In English) [CrossRef] [PubMed]

18. Nawy, S. The metabotropic receptor mGluR6 may signal through G(o), but not phosphodiesterase, in retinal bipolar cells. J. Neurosci. 1999, 19, 2938-2944. (In English) [CrossRef]

19. Chu, Z.; Hablitz, J.J. Quisqualate induces an inward current via mGluR activation in neocortical pyramidal neurons. Brain Res. 2000, 879, 88-92. (In English) [CrossRef]

20. Hermans, E.; Challiss, R.A. Structural, signalling and regulatory properties of the group I metabotropic glutamate receptors: Prototypic family C G-protein-coupled receptors. Biochem. J. 2001, 359, 465-484. (In English) [CrossRef]

21. Eng, A.G.; Kelver, D.A.; Hedrick, T.P.; Swanson, G.T. Transduction of group I mGluR-mediated synaptic plasticity by $\beta$-arrestin2 signalling. Nat. Commun. 2016, 7, 13571. (In English) [CrossRef]

22. Reiner, A.; Levitz, J. Glutamatergic Signaling in the Central Nervous System: Ionotropic and Metabotropic Receptors in Concert. Neuron 2018, 98, 1080-1098. (In English) [CrossRef] [PubMed] 
23. Valenti, O.; Conn, P.J.; Marino, M.J. Distinct physiological roles of the Gq-coupled metabotropic glutamate receptors Co-expressed in the same neuronal populations. J. Cell. Physiol. 2002, 191, 125-137. (In English) [CrossRef] [PubMed]

24. Liu, F.; Ma, X.-H.; Ule, J.; Bibb, J.A.; Nishi, A.; DeMaggio, A.J.; Yan, Z.; Nairn, A.C.; Greengard, P. Regulation of cyclin-dependent kinase 5 and casein kinase 1 by metabotropic glutamate receptors. Proc. Natl. Acad. Sci. USA 2001, 98, 11062-11068. (In English) [CrossRef] [PubMed]

25. Stevenson, R.A.; Hoffman, J.L.; Maldonado-Devincci, A.M.; Faccidomo, S.; Hodge, C.W. MGluR5 activity is required for the induction of ethanol behavioral sensitization and associated changes in ERK MAP kinase phosphorylation in the nucleus accumbens shell and lateral habenula. Behav. Brain Res. 2019, 367, 19-27. (In English) [CrossRef] [PubMed]

26. Schmit, T.L.; Dowell, J.A.; Maes, M.E.; Wilhelm, M. c-Jun N-terminal kinase regulates mGluR-dependent expression of postsynaptic FMRP target proteins. J. Neurochem. 2013, 127, 772-781. (In English) [CrossRef] [PubMed]

27. Liu, F.; Virshup, D.M.; Nairn, A.C.; Greengard, P. Mechanism of regulation of casein kinase I activity by group I metabotropic glutamate receptors. J. Biol. Chem. 2002, 277, 45393-45399. (In English) [CrossRef]

28. Pellegrini-Giampietro, D.E.; Torregrossa, S.A.; Moroni, F. Pharmacological characterization of metabotropic glutamate receptors coupled to phospholipase D in the rat hippocampus. Br. J. Pharmacol. 1996, 118, 1035-1043. (In English) [CrossRef] [PubMed]

29. Abd-Elrahman, K.S.; Ferguson, S.S.G. Modulation of mTOR and CREB pathways following mGluR5 blockade contribute to improved Huntington's pathology in zQ175 mice. Mol. Brain 2019, 12, 35. (In English) [CrossRef]

30. Maksymetz, J.; Moran, S.P.; Conn, P.J. Targeting metabotropic glutamate receptors for novel treatments of schizophrenia. Mol. Brain 2017, 10, 15. (In English) [CrossRef] [PubMed]

31. Correa, A.M.B.; Guimarães, J.D.S.; Alhadas, E.D.S.E.; Kushmerick, C. Control of neuronal excitability by Group I metabotropic glutamate receptors. Biophys. Rev. 2017, 9, 835-845. (In English) [CrossRef] [PubMed]

32. Gerber, U.; Gee, C.E.; Benquet, P. Metabotropic glutamate receptors: Intracellular signaling pathways. Curr. Opin. Pharmacol. 2007, 7, 56-61. (In English) [CrossRef] [PubMed]

33. Volk, D.W.; Eggan, S.M.; Lewis, D.A. Alterations in metabotropic glutamate receptor $1 \alpha$ and regulator of G protein signaling 4 in the prefrontal cortex in schizophrenia. Am. J. Psychiatry 2010, 167, 1489-1498. (In English) [CrossRef] [PubMed]

34. Brody, S.A.; Conquet, F.; Geyer, M.A. Disruption of prepulse inhibition in mice lacking mGluR1. Eur. J. Neurosci. 2003, 18, 3361-3366. (In English) [CrossRef] [PubMed]

35. Hikichi, H.; Nishino, M.; Fukushima, M.; Satow, A.; Maehara, S.; Kawamoto, H.; Ohta, H. Pharmacological effects of metabotropic glutamate receptor ligands on prepulse inhibition in DBA/2J mice. Eur. J. Pharmacol. 2010, 639, 99-105. (In English) [CrossRef]

36. Braff, D.L.; Grillon, C.; Geyer, M.A. Gating and habituation of the startle reflex in schizophrenic patients. Arch. Gen. Psychiatry 1992, 49, 206-215. (In English) [CrossRef] [PubMed]

37. Frank, R.A.W.; McRae, A.F.; Pocklington, A.J.; Van De Lagemaat, L.N.; Navarro, P.; Croning, M.D.R.; Komiyama, N.H.; Bradley, S.J.; Challiss, R.A.J.; Armstrong, J.D.; et al. Clustered coding variants in the glutamate receptor complexes of individuals with schizophrenia and bipolar disorder. PLoS ONE 2011, 6, e19011. (In English) [CrossRef] [PubMed]

38. Ayoub, M.A.; Angelicheva, D.; Vile, D.; Chandler, D.; Morar, B.; Cavanaugh, J.A.; Visscher, P.M.; Jablensky, A.; Pfleger, K.D.G.; Kalaydjieva, L. Deleterious GRM1 mutations in schizophrenia. PLoS ONE 2012, 7, e32849. (In English) [CrossRef] [PubMed]

39. Cho, H.P.; Garcia-Barrantes, P.M.; Brogan, J.T.; Hopkins, C.R.; Niswender, C.M.; Rodriguez, A.L.; Venable, D.F.; Morrison, R.D.; Bubser, M.; Daniels, J.S.; et al. Chemical modulation of mutant mGlu1 receptors derived from deleterious GRM1 mutations found in schizophrenics. ACS Chem. Biol. 2014, 9, 2334-2346. (In English) [CrossRef]

40. Lesage, A.; Steckler, T. Metabotropic glutamate mGlu1 receptor stimulation and blockade: Therapeutic opportunities in psychiatric illness. Eur. J. Pharmacol. 2010, 639, 2-16. (In English) [CrossRef]

41. Zoicas, I.; Kornhuber, J. The Role of Metabotropic Glutamate Receptors in Social Behavior in Rodents. Int. J. Mol. Sci. 2019, 20, 1412. (In English) [CrossRef]

42. Foster, D.J.; Conn, P.J. Allosteric Modulation of GPCRs: New Insights and Potential Utility for Treatment of Schizophrenia and Other CNS Disorders. Neuron 2017, 94, 431-446. (In English) [CrossRef]

43. Satow, A.; Maehara, S.; Ise, S.; Hikichi, H.; Fukushima, M.; Suzuki, G.; Kimura, T.; Tanaka, T.; Ito, S.; Kawamoto, H.; et al. Pharmacological effects of the metabotropic glutamate receptor 1 antagonist compared with those of the metabotropic glutamate receptor 5 antagonist and metabotropic glutamate receptor 2/3 agonist in rodents: Detailed investigations with a selective allosteric metabotropic glutamate receptor 1 antagonist, FTIDC [4-[1-(2-fluoropyridine-3-yl)-5-methyl-1H-1,2,3-triazol-4-yl]N-isopropyl-N-methyl-3,6-dihydropyridine-1(2H)-carboxamide]. J. Pharmacol. Exp. Ther. 2008, 326, 577-586. (In English) [CrossRef]

44. Conn, P.J.; Lindsley, C.W.; Jones, C.K. Activation of metabotropic glutamate receptors as a novel approach for the treatment of schizophrenia. Trends Pharmacol. Sci. 2009, 30, 25-31. (In English) [CrossRef] [PubMed]

45. Satow, A.; Suzuki, G.; Maehara, S.; Hikichi, H.; Murai, T.; Murai, T.; Kawagoe-Takaki, H.; Hata, M.; Ito, S.; Ozaki, S.; et al. Unique antipsychotic activities of the selective metabotropic glutamate receptor 1 allosteric antagonist 2-cyclopropyl-5-[1-(2-fluoro-3pyridinyl)-5-methyl-1H-1,2,3-triazol-4-yl]-2,3-dihydro-1H-isoindol-1-one. J. Pharmacol. Exp. Ther. 2009, 330, 179-190. (In English) [CrossRef] [PubMed]

46. Kinney, G.G.; Burno, M.; Campbell, U.C.; Hernandez, L.M.; Rodriguez, D.; Bristow, L.J.; Conn, P.J. Metabotropic glutamate subtype 5 receptors modulate locomotor activity and sensorimotor gating in rodents. J. Pharmacol. Exp. Ther. 2003, 306, 116-123. (In English) [CrossRef] 
47. Vales, K.; Svoboda, J.; Benkovicova, K.; Bubenikova-Valesova, V.; Stuchlik, A. The difference in effect of mGlu2/3 and mGlu5 receptor agonists on cognitive impairment induced by MK-801. Eur. J. Pharmacol. 2010, 639, 91-98. (In English) [CrossRef] [PubMed]

48. Chan, M.H.; Chiu, P.H.; Sou, J.H.; Chen, H.H. Attenuation of ketamine-evoked behavioral responses by mGluR5 positive modulators in mice. Psychopharmacology 2008, 198, 141-148. (In English) [CrossRef] [PubMed]

49. Kinney, G.G.; O’Brien, J.A.; Lemaire, W.; Burno, M.; Bickel, D.J.; Clements, M.K.; Chen, T.-B.; Wisnoski, D.D.; Lindsley, C.W.; Tiller, P.R.; et al. A novel selective positive allosteric modulator of metabotropic glutamate receptor subtype 5 has in vivo activity and antipsychotic-like effects in rat behavioral models. J. Pharmacol. Exp. Ther. 2004, 313, 199-206. (In English) [CrossRef]

50. Vardigan, J.D.; Huszar, S.L.; McNaughton, C.H.; Hutson, P.H.; Uslaner, J.M. MK-801 produces a deficit in sucrose preference that is reversed by clozapine, D-serine, and the metabotropic glutamate 5 receptor positive allosteric modulator CDPPB: Relevance to negative symptoms associated with schizophrenia? Pharmacol. Biochem. Behav. 2010, 95, 223-229. (In English) [CrossRef]

51. Stefani, M.R.; Moghaddam, B. Activation of type 5 metabotropic glutamate receptors attenuates deficits in cognitive flexibility induced by NMDA receptor blockade. Eur. J. Pharmacol. 2010, 639, 26-32. (In English) [CrossRef] [PubMed]

52. Liu, F.; Grauer, S.; Kelley, C.; Navarra, R.L.; Graf, R.; Zhang, G.; Atkinson, P.J.; Popiolek, M.; Wantuch, C.M.; Khawaja, X.; et al. ADX47273 [S-(4-fluoro-phenyl)-\{3-[3-(4-fluoro-phenyl)-(1,2,4)-oxadiazol-5-yl]-piperidin-1-yl\}-methanone]: A novel metabotropic glutamate receptor 5-selective positive allosteric modulator with preclinical antipsychotic-like and procognitive activities. J. Pharmacol. Exp. Ther. 2008, 327, 827-839. (In English) [CrossRef] [PubMed]

53. Rook, J.M.; Xiang, Z.; Lv, X.; Ghoshal, A.; Dickerson, J.W.; Bridges, T.M.; Johnson, K.A.; Foster, D.J.; Gregory, K.J.; Vinson, P.N.; et al. Biased mGlu5-Positive Allosteric Modulators Provide In Vivo Efficacy without Potentiating mGlu5 Modulation of NMDAR Currents. Neuron 2015, 86, 1029-1040. [CrossRef] [PubMed]

54. Parmentier-Batteur, S.; Hutson, P.H.; Menzel, K.; Uslaner, J.M.; Mattson, B.A.; O’Brien, J.A.; Magliaro, B.C.; Forest, T.; Stump, C.A.; Tynebor, R.M.; et al. Mechanism based neurotoxicity of mGlu5 positive allosteric modulators-Development challenges for a promising novel antipsychotic target. Neuropharmacology 2014, 82, 161-173. (In English) [CrossRef]

55. Balu, D.T.; Li, Y.; Takagi, S.; Presti, K.T.; Ramikie, T.S.; Rook, J.M.; Jones, C.K.; Lindsley, C.W.; Conn, P.J.; Bolshakov, V.Y.; et al. An mGlu5-Positive Allosteric Modulator Rescues the Neuroplasticity Deficits in a Genetic Model of NMDA Receptor Hypofunction in Schizophrenia. Neuropsychopharmacology 2016, 41, 2052-2061. (In English) [CrossRef]

56. Crupi, R.; Impellizzeri, D.; Cuzzocrea, S. Role of Metabotropic Glutamate Receptors in Neurological Disorders. Front. Mol. Neurosci. 2019, 12, 20. (In English) [CrossRef]

57. Ohishi, H.; Shigemoto, R.; Nakanishi, S.; Mizuno, N. Distribution of the mRNA for a metabotropic glutamate receptor (mGluR3) in the rat brain: An in situ hybridization study. J. Comp. Neurol. 1993, 335, 252-266. (In English) [CrossRef]

58. Ferraguti, F.; Shigemoto, R. Metabotropic glutamate receptors. Cell Tissue Res. 2006, 326, 483-504. (In English) [CrossRef] [PubMed]

59. Yin, S.; Noetzel, M.J.; Johnson, K.A.; Zamorano, R.; Jalan-Sakrikar, N.; Gregory, K.J.; Conn, P.J.; Niswender, C.M. Selective actions of novel allosteric modulators reveal functional heteromers of metabotropic glutamate receptors in the CNS. J. Neurosci. 2014, 34, 79-94. (In English) [CrossRef] [PubMed]

60. Di Menna, L.; Joffe, M.E.; Iacovelli, L.; Orlando, R.; Lindsley, C.W.; Mairesse, J.; Gressèns, P.; Cannella, M.; Caraci, F.; Copani, A.; et al. Functional partnership between mGlu3 and mGlu5 metabotropic glutamate receptors in the central nervous system. Neuropharmacology 2018, 128, 301-313. (In English) [CrossRef] [PubMed]

61. Pehrson, A.L.; Moghaddam, B. Impact of metabotropic glutamate 2/3 receptor stimulation on activated dopamine release and locomotion. Psychopharmacology 2010, 211, 443-455. (In English) [CrossRef] [PubMed]

62. Moghaddam, B.; Adams, B.W. Reversal of phencyclidine effects by a group II metabotropic glutamate receptor agonist in rats. Science 1998, 281, 1349-1352. (In English) [CrossRef] [PubMed]

63. Uslaner, J.M.; Smith, S.M.; Huszar, S.L.; Pachmerhiwala, R.; Hinchliffe, R.M.; Vardigan, J.D.; Hutson, P.H. Combined administration of an mGlu2/3 receptor agonist and a 5-HT 2A receptor antagonist markedly attenuate the psychomotor-activating and neurochemical effects of psychostimulants. Psychopharmacology 2009, 206, 641-651. (In English) [CrossRef] [PubMed]

64. Krystal, J.H.; Abi-Saab, W.; Perry, E.; D’Souza, D.C.; Liu, N.; Gueorguieva, R.; McDougall, L.; Hunsberger, T.; Belger, A.; Levine, L.; et al. Preliminary evidence of attenuation of the disruptive effects of the NMDA glutamate receptor antagonist, ketamine, on working memory by pretreatment with the group II metabotropic glutamate receptor agonist, LY354740, in healthy human subjects. Psychopharmacology 2004, 179, 303-309. (In English) [CrossRef] [PubMed]

65. Lorrain, D.S.; Baccei, C.S.; Bristow, L.J.; Anderson, J.J.; Varney, M.A. Effects of ketamine and N-methyl-D-aspartate on glutamate and dopamine release in the rat prefrontal cortex: Modulation by a group II selective metabotropic glutamate receptor agonist LY379268. Neuroscience 2003, 117, 697-706. (In English) [CrossRef]

66. Spampinato, S.F.; Copani, A.; Nicoletti, F.; Sortino, M.A.; Caraci, F. Metabotropic Glutamate Receptors in Glial Cells: A New Potential Target for Neuroprotection? Front. Mol. Neurosci. 2018, 11, 414. (In English) [CrossRef] [PubMed]

67. Ster, J.; Mateos, J.M.; Grewe, B.F.; Coiret, G.; Corti, C.; Corsi, M.; Helmchen, F.; Gerber, U. Enhancement of CA3 hippocampal network activity by activation of group II metabotropic glutamate receptors. Proc. Natl. Acad. Sci. USA 2011, 108, 9993-9997. (In English) [CrossRef] 
68. González-Maeso, J.; Ang, R.L.; Yuen, T.; Chan, P.; Weisstaub, N.V.; López-Giménez, J.F.; Zhou, M.; Okawa, Y.; Callado, L.F.; Milligan, G.; et al. Identification of a serotonin/glutamate receptor complex implicated in psychosis. Nature 2008, $452,93-97$. (In English) [CrossRef]

69. Moreno, J.L.; Holloway, T.; Albizu, L.; Sealfon, S.C.; González-Maeso, J. Metabotropic glutamate mGlu2 receptor is necessary for the pharmacological and behavioral effects induced by hallucinogenic 5-HT2A receptor agonists. Neurosci. Lett. 2011, 493, 76-79. (In English) [CrossRef]

70. Kurita, M.; Holloway, T.; García-Bea, A.; Kozlenkov, A.; Friedman, A.K.; Moreno, J.L.; Heshmati, M.; Golden, S.A.; Kennedy, P.J.; Takahashi, N.; et al. HDAC2 regulates atypical antipsychotic responses through the modulation of mGlu2 promoter activity. Nat. Neurosci. 2012, 15, 1245-1254. (In English) [CrossRef] [PubMed]

71. Woolley, M.L.; Pemberton, D.J.; Bate, S.; Corti, C.; Jones, D.N. The mGlu2 but not the mGlu3 receptor mediates the actions of the mGluR2/3 agonist, LY379268, in mouse models predictive of antipsychotic activity. Psychopharmacology 2008, 196, 431-440. (In English) [CrossRef] [PubMed]

72. Cartmell, J.; Monn, J.A.; Schoepp, D.D. The metabotropic glutamate 2/3 receptor agonists LY354740 and LY379268 selectively attenuate phencyclidine versus d-amphetamine motor behaviors in rats. J. Pharmacol. Exp. Ther. 1999, 291, 161-170. (In English)

73. Cartmell, J.; Monn, J.A.; Schoepp, D.D. The $\mathrm{mGlu(2/3)}$ receptor agonist LY379268 selectively blocks amphetamine ambulations and rearing. Eur. J. Pharmacol. 2000, 400, 221-224. [CrossRef]

74. Cartmell, J.; Monn, J.A.; Schoepp, D.D. Attenuation of specific PCP-evoked behaviors by the potent mGlu2/3 receptor agonist, LY379268 and comparison with the atypical antipsychotic, clozapine. Psychopharmacology 2000, 148, 423-429. (In English) [CrossRef]

75. Galici, R.; Echemendia, N.G.; Rodriguez, A.L.; Conn, P.J. A selective allosteric potentiator of metabotropic glutamate (mGlu) 2 receptors has effects similar to an orthosteric mGlu2/3 receptor agonist in mouse models predictive of antipsychotic activity. J. Pharmacol. Exp. Ther. 2005, 315, 1181-1187. (In English) [CrossRef]

76. Schlumberger, C.; Schäfer, D.; Barberi, C.; Morè, L.; Nagel, J.; Pietraszek, M.; Schmidt, W.J.; Danysz, W. Effects of a metabotropic glutamate receptor group II agonist LY354740 in animal models of positive schizophrenia symptoms and cognition. Behav. Pharmacol. 2009, 20, 56-66. (In English) [CrossRef]

77. Profaci, C.P.; Krolikowski, K.A.; Olszewski, R.T.; Neale, J.H. Group II mGluR agonist LY354740 and NAAG peptidase inhibitor effects on prepulse inhibition in PCP and D-amphetamine models of schizophrenia. Psychopharmacology 2011, 216, 235-243. (In English) [CrossRef] [PubMed]

78. Harich, S.; Gross, G.; Bespalov, A. Stimulation of the metabotropic glutamate 2/3 receptor attenuates social novelty discrimination deficits induced by neonatal phencyclidine treatment. Psychopharmacology 2007, 192, 511-519. (In English) [CrossRef] [PubMed]

79. Chartoff, E.H.; Heusner, C.L.; Palmiter, R.D. Dopamine is not required for the hyperlocomotor response to NMDA receptor antagonists. Neuropsychopharmacology 2005, 30, 1324-1333. (In English) [CrossRef]

80. Rorick-Kehn, L.M.; Perkins, E.J.; Knitowski, K.M.; Hart, J.C.; Johnson, B.G.; Schoepp, D.D.; McKinzie, D.L. Improved bioavailability of the mGlu2/3 receptor agonist LY354740 using a prodrug strategy: In vivo pharmacology of LY544344. J. Pharmacol. Exp. Ther. 2005, 316, 905-913. (In English) [CrossRef] [PubMed]

81. Imre, G.; Salomons, A.; Jongsma, M.; Fokkema, D.S.; den Boer, J.A.; Horst, G.J.T. Effects of the mGluR2/3 agonist LY379268 on ketamine-evoked behaviours and neurochemical changes in the dentate gyrus of the rat. Pharmacol. Biochem. Behav. 2006, 84, 392-399. (In English) [CrossRef] [PubMed]

82. Xi, D.; Li, Y.-C.; Snyder, M.A.; Gao, R.Y.; Adelman, A.E.; Zhang, W.; Shumsky, J.S.; Gao, W.-J. Group II metabotropic glutamate receptor agonist ameliorates MK801-induced dysfunction of NMDA receptors via the Akt/GSK-3 $\beta$ pathway in adult rat prefrontal cortex. Neuropsychopharmacology 2011, 36, 1260-1274. (In English) [CrossRef] [PubMed]

83. Winter, J.C.; Eckler, J.R.; Rabin, R.A. Serotonergic/glutamatergic interactions: The effects of mGlu2/3 receptor ligands in rats trained with LSD and PCP as discriminative stimuli. Psychopharmacology 2004, 172, 233-240. (In English) [CrossRef]

84. Lorrain, D.S.; Schaffhauser, H.; Campbell, U.C.; Baccei, C.S.; Correa, L.D.; Rowe, B.; Rodriguez, D.E.; Anderson, J.J.; Varney, M.A.; Pinkerton, A.B.; et al. Group II mGlu receptor activation suppresses norepinephrine release in the ventral hippocampus and locomotor responses to acute ketamine challenge. Neuropsychopharmacology 2003, 28, 1622-1632. (In English) [CrossRef]

85. Swanson, C.J.; Schoepp, D.D. The group II metabotropic glutamate receptor agonist (-)-2-oxa-4-aminobicyclo (3.1.0.)hexane-4,6dicarboxylate (LY379268) and clozapine reverse phencyclidine-induced behaviors in monoamine-depleted rats. J. Pharmacol. Exp. Ther. 2002, 303, 919-927. (In English) [CrossRef] [PubMed]

86. Engel, M.; Snikeris, P.; Matosin, N.; Newell, K.A.; Huang, X.F.; Frank, E. mGluR2/3 agonist LY379268 rescues NMDA and GABAA receptor level deficits induced in a two-hit mouse model of schizophrenia. Psychopharmacology 2016, 233, 1349-1359. (In English) [CrossRef] [PubMed]

87. Sokolenko, E.; Hudson, M.R.; Nithianantharajah, J.; Jones, N.C. The mGluR. J. Psychopharmacol. 2019, 33, 1588-1599. (In English) [CrossRef] [PubMed]

88. Jones, C.A.; Brown, A.M.; Auer, D.P.; Fone, K.C. The mGluR2/3 agonist LY379268 reverses post-weaning social isolation-induced recognition memory deficits in the rat. Psychopharmacology 2011, 214, 269-283. (In English) [CrossRef] [PubMed]

89. Matrisciano, F.; Dong, E.; Nicoletti, F.; Guidotti, A. Epigenetic Alterations in Prenatal Stress Mice as an Endophenotype Model for Schizophrenia: Role of Metabotropic Glutamate 2/3 Receptors. Front. Mol. Neurosci. 2018, 11, 423. (In English) [CrossRef] [PubMed] 
90. Holloway, T.; Moreno, J.L.; Umali, A.; Rayannavar, V.; Hodes, G.E.; Russo, S.J.; González-Maeso, J. Prenatal stress induces schizophrenia-like alterations of serotonin $2 \mathrm{~A}$ and metabotropic glutamate 2 receptors in the adult offspring: Role of maternal immune system. J. Neurosci. 2013, 33, 1088-1098. (In English) [CrossRef] [PubMed]

91. Xing, B.; Han, G.; Wang, M.J.; Snyder, M.A.; Gao, W.J. Juvenile treatment with mGluR2/3 agonist prevents schizophrenia-like phenotypes in adult by acting through GSK3ß. Neuropharmacology 2018, 137, 359-371. (In English) [CrossRef]

92. Li, M.-L.; Gulchina, Y.; Monaco, S.A.; Xing, B.; Ferguson, B.R.; Li, Y.-C.; Li, F.; Hu, X.-Q.; Gao, W.-J. Juvenile treatment with a novel mGluR2 agonist/mGluR3 antagonist compound, LY395756, reverses learning deficits and cognitive flexibility impairments in adults in a neurodevelopmental model of schizophrenia. Neurobiol. Learn. Mem. 2017, 140, 52-61. (In English) [CrossRef] [PubMed]

93. Riegel, A.C.; Ali, S.F.; French, E.D. Toluene-induced locomotor activity is blocked by 6-hydroxydopamine lesions of the nucleus accumbens and the mGluR2/3 agonist LY379268. Neuropsychopharmacology 2003, 28, 1440-1447. (In English) [CrossRef] [PubMed]

94. Cartmell, J.; Monn, J.A.; Schoepp, D.D. Tolerance to the motor impairment, but not to the reversal of PCP-induced motor activities by oral administration of the mGlu2/3 receptor agonist, LY379268. Naunyn Schmiedeberg Arch. Pharmacol. 2000, 361, 39-46. (In English) [CrossRef] [PubMed]

95. Schoepp, D.; Marek, G. Preclinical pharmacology of mGlu2/3 receptor agonists: Novel agents for schizophrenia? Curr. Drug Target CNS Neurol. Disord. 2002, 1, 215-225. (In English) [CrossRef] [PubMed]

96. Burgos-Aguilar, C.; Ferris, M.J.; Sexton, L.L.; Sun, H.; Xiao, R.; Chen, R.; Childers, S.R.; Howlett, A.C. Metabotropic glutamate 2,3 receptor stimulation desensitizes agonist activation of G-protein signaling and alters transcription regulators in mesocorticolimbic brain regions. Synapse 2021, 75, e22190. (In English) [CrossRef] [PubMed]

97. Nikiforuk, A.; Popik, P.; Drescher, K.U.; Van Gaalen, M.; Relo, A.-L.; Mezler, M.; Marek, G.; Schoemaker, H.; Gross, G.; Bespalov, A. Effects of a positive allosteric modulator of group II metabotropic glutamate receptors, LY487379, on cognitive flexibility and impulsive-like responding in rats. J. Pharmacol. Exp. Ther. 2010, 335, 665-673. (In English) [CrossRef] [PubMed]

98. Hikichi, H.; Kaku, A.; Karasawa, J.; Chaki, S. Stimulation of metabotropic glutamate (mGlu) 2 receptor and blockade of mGlu1 receptor improve social memory impairment elicited by MK-801 in rats. J. Pharmacol. Sci. 2013, 122, 10-16. (In English) [CrossRef]

99. Benneyworth, M.A.; Xiang, Z.; Smith, R.L.; Garcia, E.E.; Conn, P.J.; Sanders-Bush, E. A selective positive allosteric modulator of metabotropic glutamate receptor subtype 2 blocks a hallucinogenic drug model of psychosis. Mol. Pharmacol. 2007, 72, 477-484. (In English) [CrossRef]

100. Lavreysen, H.; Ahnaou, A.; Drinkenburg, W.; Langlois, X.; Mackie, C.; Pype, S.; Lutjens, R.; Le Poul, E.; Trabanco, A.A.; Nuñez, J.M.C. Pharmacological and pharmacokinetic properties of JNJ-40411813, a positive allosteric modulator of the mGlu2 receptor. Pharmacol. Res. Perspect. 2015, 3, e00096. (In English) [CrossRef] [PubMed]

101. Griebel, G.; Pichat, P.; Boulay, D.; Naimoli, V.; Potestio, L.; Featherstone, R.; Sahni, S.; DeFex, H.; Desvignes, C.; Slowinski, F.; et al. The mGluR2 positive allosteric modulator, SAR218645, improves memory and attention deficits in translational models of cognitive symptoms associated with schizophrenia. Sci. Rep. 2016, 6, 35320. (In English) [CrossRef] [PubMed]

102. Patil, S.T.; Zhang, L.; Martenyi, F.; Lowe, S.L.; Jackson, K.A.; Andreev, B.V.; Avedisova, A.S.; Bardenstein, L.M.; Gurovich, I.Y.; Morozova, M.A.; et al. Activation of mGlu2/3 receptors as a new approach to treat schizophrenia: A randomized Phase 2 clinical trial. Nat. Med. 2007, 13, 1102-1107. (In English) [CrossRef] [PubMed]

103. Kinon, B.J.; Gómez, J.C. Clinical development of pomaglumetad methionil: A non-dopaminergic treatment for schizophrenia. Neuropharmacology 2013, 66, 82-86. (In English) [CrossRef] [PubMed]

104. Adams, D.H.; Kinon, B.J.; Baygani, S.; Millen, B.A.; Velona, I.; Kollack-Walker, S.; Walling, D.P. A long-term, phase 2, multicenter randomized, open-label, comparative safety study of pomaglumetad methionil (LY2140023 monohydrate) versus atypical antipsychotic standard of care in pa tients with schizophrenia. BMC Psychiatry 2013, 13, 143. (In English) [CrossRef] [PubMed]

105. Li, M.L.; Hu, X.Q.; Li, F.; Gao, W.J. Perspectives on the mGluR2/3 agonists as a therapeutic target for schizophrenia: Still promising or a dead end? Prog. Neuro Psychopharmacol. Biol. Psychiatry 2015, 60, 66-76. (In English) [CrossRef]

106. Hopkins, C.R. Is there a path forward for mGlu(2) positive allosteric modulators for the treatment of schizophrenia? ACS Chem. Neurosci. 2012, 4, 211-213. (In English) [CrossRef] [PubMed]

107. Salih, H.; Anghelescu, I.; Kezic, I.; Sinha, V.; Hoeben, E.; Van Nueten, L.; De Smedt, H.; De Boer, P. Pharmacokinetic and pharmacodynamic characterisation of JNJ-40411813, a positive allosteric modulator of mGluR2, in two randomised, double-blind phase-I studies. J. Psychopharmacol. 2014, 29, 414-425. (In English) [CrossRef]

108. Litman, R.E.; Smith, M.A.; Doherty, J.J.; Cross, A.; Raines, S.; Gertsik, L.; Zukin, S.R. AZD8529, a positive allosteric modulator at the mGluR2 receptor, does not improve symptoms in schizophrenia: A proof of principle study. Schizophr. Res. 2016, 172, 152-157. (In English) [CrossRef]

109. Javitt, D.C.; Carter, C.S.; Krystal, J.H.; Kantrowitz, J.T.; Girgis, R.R.; Kegeles, L.S.; Ragland, J.D.; Maddock, R.J.; Lesh, T.A.; Tanase, C.; et al. Utility of Imaging-Based Biomarkers for Glutamate-Targeted Drug Development in Psychotic Disorders: A Randomized Clinical Trial. JAMA Psychiatry 2018, 75, 11-19. (In English) [CrossRef] [PubMed]

110. Kantrowitz, J.T.; Grinband, J.; Goff, D.C.; Lahti, A.C.; Marder, S.R.; Kegeles, L.S.; Girgis, R.R.; Sobeih, T.; Wall, M.M.; Choo, T.H.; et al. Proof of mechanism and target engagement of glutamatergic drugs for the treatment of schizophrenia: RCTs of pomaglumetad and TS-134 on ketamine-induced psychotic symptoms and pharmacoBOLD in healthy volunteers. Neuropsychopharmacology 2020, 45, 1842-1850. (In English) [CrossRef] [PubMed] 
111. Tandon, R.; Keshavan, M.S.; Nasrallah, H.A. Schizophrenia, "Just the Facts": What we know in 2008 part 1: Overview. Schizophr. Res. 2008, 100, 4-19. (In English) [CrossRef] [PubMed]

112. Miyamoto, S.; Duncan, G.E.; Marx, C.E.; Lieberman, J.A. Treatments for schizophrenia: A critical review of pharmacology and mechanisms of action of antipsychotic drugs. Mol. Psychiatry 2004, 10, 79-104. (In English) [CrossRef]

113. Ayan-Oshodi, M.; Wondmagegnehu, E.T.; Lowe, S.L.; Kryzhanovskaya, L.; Walker, D.J.; Kinon, B.J. Adverse events in healthy subjects exposed to single and multiple doses of LY2140023 monohydrate: Pooled results from 10 phase 1 studies. J. Clin. Psychopharmacol. 2012, 32, 408-411. (In English) [CrossRef]

114. Stauffer, V.L.; Baygani, S.K.; Kinon, B.J.; Krikke-Workel, J.O. A short-term, multicenter, placebo-controlled, randomized withdrawal study of a metabotropic glutamate 2/3 receptor agonist using an electronic patient-reported outcome device in patients with schizophrenia. J Clin Psychopharmacol. J. Clin. Psychopharmacol. 2014, 34, 552-558. (In English) [CrossRef] [PubMed]

115. Chue, P.; Lalonde, J.K. Addressing the unmet needs of patients with persistent negative symptoms of schizophrenia: Emerging pharmacological treatment options. Neuropsychiatr. Dis. Treat. 2014, 10, 777-789. (In English) [CrossRef]

116. Adams, D.H.; Zhang, L.; Millen, B.A.; Kinon, B.J.; Gomez, J.C. Pomaglumetad Methionil (LY2140023 Monohydrate) and Aripiprazole in Patients with Schizophrenia: A Phase 3, Multicenter, Double-Blind Comparison. Schizophr. Res. Treat. 2014, 2014, 758212. (In English) [CrossRef] [PubMed]

117. Cartmell, J.; Schoepp, D.D. Regulation of neurotransmitter release by metabotropic glutamate receptors. J. Neurochem. 2002, 75, 889-907. (In English) [CrossRef]

118. Lorez, M.; Humbel, U.; Pflimlin, M.C.; Kew, J.N. Group III metabotropic glutamate receptors as autoreceptors in the cerebellar cortex. Br. J. Pharmacol. 2003, 138, 614-625. (In English) [CrossRef]

119. Pekhletski, R.; Gerlai, R.; Overstreet, L.S.; Huang, X.-P.; Agopyan, N.; Slater, N.T.; Abramow-Newerly, W.; Roder, J.C.; Hampson, D.R. Impaired cerebellar synaptic plasticity and motor performance in mice lacking the mGluR4 subtype of metabotropic glutamate receptor. J. Neurosci. 1996, 16, 6364-6373. (In English) [CrossRef]

120. Nakajima, Y.; Iwakabe, H.; Akazawa, C.; Nawa, H.; Shigemoto, R.; Mizuno, N.; Nakanishi, S. Molecular characterization of a novel retinal metabotropic glutamate receptor mGluR6 with a high agonist selectivity for L-2-amino-4-phosphonobutyrate. J. Biol. Chem. 1993, 268, 11868-11873. (In English) [CrossRef]

121. Corti, C.; Aldegheri, L.; Somogyi, P.; Ferraguti, F. Distribution and synaptic localisation of the metabotropic glutamate receptor 4 (mGluR4) in the rodent CNS. Neuroscience 2002, 110, 403-420. (In English) [CrossRef]

122. Daniel, H.; Crepel, F. Control of $\mathrm{Ca}(2+)$ influx by cannabinoid and metabotropic glutamate receptors in rat cerebellar cortex requires K (+) channels. J. Physiol. 2001, 537, 793-800. (In English) [CrossRef]

123. Abitbol, K.; Acher, F.; Daniel, H. Depression of excitatory transmission at PF-PC synapse by group III metabotropic glutamate receptors is provided exclusively by mGluR4 in the rodent cerebellar cortex. J. Neurochem. 2008, 105, 2069-2079. (In English) [CrossRef] [PubMed]

124. Weber, M.; Schnitzler, H.U.; Schmid, S. Synaptic plasticity in the acoustic startle pathway: The neuronal basis for short-term habituation? Eur. J. Neurosci. 2002, 16, 1325-1332. (In English) [CrossRef] [PubMed]

125. Goddyn, H.; Callaerts-Vegh, Z.; D’Hooge, R. Functional Dissociation of Group III Metabotropic Glutamate Receptors Revealed by Direct Comparison between the Behavioral Profiles of Knockout Mouse Lines. Int. J. Neuropsychopharmacol. 2015, 18, pyv053. (In English) [CrossRef] [PubMed]

126. Bruno, V.; Battaglia, G.; Książek, I.; Van Der Putten, H.; Catania, M.V.; Giuffrida, R.; Lukic, S.; Leonhardt, T.; Inderbitzin, W.; Gasparini, F.; et al. Selective activation of mGlu4 metabotropic glutamate receptors is protective against excitotoxic neuronal death. J. Neurosci. 2000, 20, 6413-6420. (In English) [CrossRef] [PubMed]

127. Senter, R.K.; Ghoshal, A.; Walker, A.G.; Xiang, Z.; Niswender, C.M.; Conn, P.J. The Role of mGlu Receptors in Hippocampal Plasticity Deficits in Neurological and Psychiatric Disorders: Implications for Allosteric Modulators as Novel Therapeutic Strategies. Curr. Neuropharmacol. 2016, 14, 455-473. (In English) [CrossRef]

128. Mena, A.; Ruiz-Salas, J.C.; Puentes, A.; Dorado, I.; Ruiz-Veguilla, M.; de la Casa, L.G. Reduced Prepulse Inhibition as a Biomarker of Schizophrenia. Front. Behav. Neurosci. 2016, 10, 202. (In English) [CrossRef] [PubMed]

129. Swerdlow, N.R.; Weber, M.; Qu, Y.; Light, G.A.; Braff, D.L. Realistic expectations of prepulse inhibition in translational models for schizophrenia research. Psychopharmacology 2008, 199, 331-388. (In English) [CrossRef]

130. Beurrier, C.; Lopez, S.; Révy, D.; Selvam, C.; Goudet, C.; Lhérondel, M.; Gubellini, P.; Kerkerian-Legoff, L.; Acher, F.; Pin, J.-P.; et al. Electrophysiological and behavioral evidence that modulation of metabotropic glutamate receptor 4 with a new agonist reverses experimental parkinsonism. FASEB J. 2009, 23, 3619-3628. (In English) [CrossRef] [PubMed]

131. Wierońska, J.M.; Stachowicz, K.; Acher, F.; Lech, T.; Pilc, A. Opposing efficacy of group III mGlu receptor activators, LSP1-2111 and AMN082, in animal models of positive symptoms of schizophrenia. Psychopharmacology 2012, 220, 481-494. (In English) [CrossRef] [PubMed]

132. Wierońska, J.M.; Acher, F.C.; Sławińska, A.; Gruca, P.; Łasoń-Tyburkiewicz, M.; Papp, M.; Pilc, A. The antipsychotic-like effects of the mGlu group III orthosteric agonist, LSP1-2111, involves 5-HT 1 A signalling. Psychopharmacology 2013, 227, 711-725. (In English) [CrossRef] [PubMed]

133. Woźniak, M.; Gołembiowska, K.; Noworyta-Sokołowska, K.; Acher, F.; Cieślik, P.; Kusek, M.; Tokarski, K.; Pilc, A.; Wierońska, J.M. Neurochemical and behavioral studies on the 5-HT. Neuropharmacology 2017, 115, 149-165. (In English) [CrossRef] [PubMed] 
134. Woźniak, M.; Acher, F.; Marciniak, M.; Lasoń-Tyburkiewicz, M.; Gruca, P.; Papp, M.; Pilc, A.; Wierońska, J.M. Involvement of GABAB Receptor Signaling in Antipsychotic-like Action of the Novel Orthosteric Agonist of the mGlu4 Receptor, LSP4-2022. Curr. Neuropharmacol. 2016, 14, 413-426. (In English) [CrossRef] [PubMed]

135. Cieślik, P.; Woźniak, M.; Rook, J.M.; Tantawy, M.N.; Conn, P.J.; Acher, F.; Tokarski, K.; Kusek, M.; Pilc, A.; Wierońska, J.M. Mutual activation of glutamatergic mGlu. Psychopharmacology 2018, 235, 2897-2913. (In English) [CrossRef] [PubMed]

136. Sławińska, A.; Wierońska, J.M.; Stachowicz, K.; Marciniak, M.; Łasoń-Tyburkiewicz, M.; Gruca, P.; Papp, M.; Kusek, M.; Tokarski, K.; Doller, D.; et al. The antipsychotic-like effects of positive allosteric modulators of metabotropic glutamate mGlu4 receptors in rodents. Br. J. Pharmacol. 2013, 169, 1824-1839. (In English) [CrossRef]

137. Kalinichev, M.; Le Poul, E.; Boléa, C.; Girard, F.; Campo, B.; Fonsi, M.; Royer-Urios, I.; Browne, S.E.; Uslaner, J.M.; Davis, M.J.; et al. Characterization of the novel positive allosteric modulator of the metabotropic glutamate receptor 4 ADX88178 in rodent models of neuropsychiatric disorders. J. Pharmacol. Exp. Ther. 2014, 350, 495-505. (In English) [CrossRef]

138. Fazio, F.; Lionetto, L.; Molinaro, G.; Bertrand, H.O.; Acher, F.; Ngomba, R.T.; Notartomaso, S.; Curini, M.; Rosati, O.; Scarselli, P.; et al. Cinnabarinic acid, an endogenous metabolite of the kynurenine pathway, activates type 4 metabotropic glutamate receptors. Mol. Pharmacol. 2012, 81, 643-656. (In English) [CrossRef]

139. Ulivieri, M.; Wierońska, J.M.; Lionetto, L.; Martinello, K.; Cieslik, P.; Chocyk, A.; Curto, M.; Di Menna, L.; Iacovelli, L.; Traficante, A.; et al. The Trace Kynurenine, Cinnabarinic Acid, Displays Potent Antipsychotic-Like Activity in Mice and Its Levels Are Reduced in the Prefrontal Cortex of Individuals Affected by Schizophrenia. Schizophr. Bull. 2020, 46, 1471-1481. (In English) [CrossRef]

140. Cieślik, P.; Woźniak, M.; Kaczorowska, K.; Brański, P.; Burnat, G.; Chocyk, A.; Bobula, B.; Gruca, P.; Litwa, E.; PałuchaPoniewiera, A.; et al. Negative Allosteric Modulators of mGlu. Front. Mol. Neurosci. 2018, 11, 316. (In English) [CrossRef]

141. Ossowska, K.; Pietraszek, M.; Wardas, J.; Wolfarth, S. Potential antipsychotic and extrapyramidal effects of (R,S)-3,4dicarboxyphenylglycine [(R,S)-3,4-DCPG], a mixed AMPA antagonist/mGluR8 agonist. Pol. J. Pharmacol. 2004, 56, 295-304. (In English) [PubMed]

142. Pinheiro, P.S.; Mulle, C. Presynaptic glutamate receptors: Physiological functions and mechanisms of action. Nat. Rev. Neurosci. 2008, 9, 423-436. (In English) [CrossRef]

143. Summa, M.; di Prisco, S.; Grilli, M.; Usai, C.; Marchi, M.; Pittaluga, A. Presynaptic mGlu7 receptors control GABA release in mouse hippocampus. Neuropharmacology 2013, 66, 215-224. (In English) [CrossRef] [PubMed]

144. Kwon, H.B.; Castillo, P.E. Role of glutamate autoreceptors at hippocampal mossy fiber synapses. Neuron 2008, 60, 1082-1094. (In English) [CrossRef]

145. Somogyi, P.; Dalezios, Y.; Luján, R.; Roberts, J.D.; Watanabe, M.; Shigemoto, R. High level of mGluR7 in the presynaptic active zones of select populations of GABAergic terminals innervating interneurons in the rat hippocampus. Eur. J. Neurosci. 2003, 17, 2503-2520. (In English) [CrossRef] [PubMed]

146. Palazzo, E.; Marabese, I.; de Novellis, V.; Rossi, F.; Maione, S. Metabotropic Glutamate Receptor 7: From Synaptic Function to Therapeutic Implications. Curr. Neuropharmacol. 2016, 14, 504-513. (In English) [CrossRef]

147. Schoepp, D.D.; Jane, D.E.; Monn, J.A. Pharmacological agents acting at subtypes of metabotropic glutamate receptors. Neuropharmacology 1999, 38, 1431-1476. (In English) [CrossRef]

148. Dunn, H.A.; Patil, D.N.; Cao, Y.; Orlandi, C.; Martemyanov, K.A. Synaptic adhesion protein ELFN1 is a selective allosteric modulator of group III metabotropic glutamate receptors. Proc. Natl. Acad. Sci. USA 2018, 115, 5022-5027. (In English) [CrossRef] [PubMed]

149. Stachniak, T.J.; Sylwestrak, E.L.; Scheiffele, P.; Hall, B.J.; Ghosh, A. Elfn1-Induced Constitutive Activation of mGluR7 Determines Frequency-Dependent Recruitment of Somatostatin Interneurons. J. Neurosci. 2019, 39, 4461-4474. (In English) [CrossRef]

150. O'Connor, R.M.; Finger, B.C.; Flor, P.J.; Cryan, J.F. Metabotropic glutamate receptor 7: At the interface of cognition and emotion. Eur. J. Pharmacol. 2010, 639, 123-131. (In English) [CrossRef] [PubMed]

151. Callaerts-Vegh, Z.; Beckers, T.; Ball, S.M.; Baeyens, F.; Callaerts, P.F.; Cryan, J.F.; Molnar, E.; D’Hooge, R. Concomitant deficits in working memory and fear extinction are functionally dissociated from reduced anxiety in metabotropic glutamate receptor 7-deficient mice. J. Neurosci. 2006, 26, 6573-6582. (In English) [CrossRef] [PubMed]

152. Masugi, M.; Yokoi, M.; Shigemoto, R.; Muguruma, K.; Watanabe, Y.; Sansig, G.; Van Der Putten, H.; Nakanishi, S. Metabotropic glutamate receptor subtype 7 ablation causes deficit in fear response and conditioned taste aversion. J. Neurosci. 1999, 19, 955-963. (In English) [CrossRef]

153. Stachowicz, K.; Brañski, P.; Kłak, K.; van der Putten, H.; Cryan, J.F.; Flor, P.J.; Andrzej, P. Selective activation of metabotropic G-protein-coupled glutamate 7 receptor elicits anxiolytic-like effects in mice by modulating GABAergic neurotransmission. Behav. Pharmacol. 2008, 19, 597-603. (In English) [CrossRef] [PubMed]

154. Tassin, V.; Girard, B.; Chotte, A.; Fontanaud, P.; Rigault, D.; Kalinichev, M.; Perroy, J.; Acher, F.; Fagni, L.; Bertaso, F. Phasic and Tonic mGlu7 Receptor Activity Modulates the Thalamocortical Network. Front. Neural Circuits 2016, 10, 31. (In English) [CrossRef] [PubMed]

155. Mitsukawa, K.; Yamamoto, R.; Ofner, S.; Nozulak, J.; Pescott, O.; Lukic, S.; Stoehr, N.; Mombereau, C.; Kuhn, R.; McAllister, K.H.; et al. A selective metabotropic glutamate receptor 7 agonist: Activation of receptor signaling via an allosteric site modulates stress parameters in vivo. Proc. Natl. Acad. Sci. USA 2005, 102, 18712-18717. (In English) [CrossRef] [PubMed] 
156. Darmani, N.A.; Martin, B.R.; Pandey, U.; Glennon, R.A. Do functional relationships exist between 5-HT1A and 5-HT2 receptors? Pharmacol. Biochem. Behav. 1990, 36, 901-906. (In English) [CrossRef]

157. Suzuki, G.; Tsukamoto, N.; Fushiki, H.; Kawagishi, A.; Nakamura, M.; Kurihara, H.; Mitsuya, M.; Ohkubo, M.; Ohta, H. In vitro pharmacological characterization of novel isoxazolopyridone derivatives as allosteric metabotropic glutamate receptor 7 antagonists. J. Pharmacol. Exp. Ther. 2007, 323, 147-156. (In English) [CrossRef] [PubMed]

158. Kalinichev, M.; Rouillier, M.; Girard, F.; Royer-Urios, I.; Bournique, B.; Finn, T.; Charvin, D.; Campo, B.; Le Poul, E.; Mutel, V.; et al. ADX71743, a potent and selective negative allosteric modulator of metabotropic glutamate receptor 7: In vitro and in vivo characterization. J. Pharmacol. Exp. Ther. 2012, 344, 624-636. (In English) [CrossRef]

159. Duvoisin, R.M.; Zhang, C.; Ramonell, K. A novel metabotropic glutamate receptor expressed in the retina and olfactory bulb. J. Neurosci. 1995, 15, 3075-3083. (In English) [CrossRef]

160. Robbins, M.J.; Starr, K.R.; Honey, A.; Soffin, E.M.; Rourke, C.; Jones, G.A.; Kelly, F.M.; Strum, J.; Melarange, R.A.; Harris, A.J.; et al. Evaluation of the mGlu8 receptor as a putative therapeutic target in schizophrenia. Brain Res. 2007, 1152, 215-227. (In English) [CrossRef] [PubMed]

161. Shigemoto, R.; Kinoshita, A.; Wada, E.; Nomura, S.; Ohishi, H.; Takada, M.; Flor, P.J.; Neki, A.; Abe, T.; Nakanishi, S.; et al. Differential presynaptic localization of metabotropic glutamate receptor subtypes in the rat hippocampus. J. Neurosci. 1997, 17, 7503-7522. (In English) [CrossRef] [PubMed]

162. Bushell, T.J.; Jane, D.E.; Tse, H.W.; Watkins, J.C.; Garthwaite, J.; Collingridge, G.L. Pharmacological antagonism of the actions of group II and III mGluR agonists in the lateral perforant path of rat hippocampal slices. Br. J. Pharmacol. 1996, 117, $1457-1462$. (In English) [CrossRef]

163. Gerlai, R.; Adams, B.; Fitch, T.; Chaney, S.; Baez, M. Performance deficits of mGluR8 knockout mice in learning tasks: The effects of null mutation and the background genotype. Neuropharmacology 2002, 43, 235-249. (In English) [CrossRef]

164. Davis, M.J.; Duvoisin, R.M.; Raber, J. Related functions of mGlu4 and mGlu8. Pharmacol. Biochem. Behav. 2013, 111, 11-16. (In English) [CrossRef] [PubMed]

165. Fendt, M.; Bürki, H.; Imobersteg, S.; Van Der Putten, H.; McAllister, K.; Leslie, J.C.; Shaw, D.; Hölscher, C. The effect of mGlu8 deficiency in animal models of psychiatric diseases. Genes Brain Behav. 2010, 9, 33-44. (In English) [CrossRef] [PubMed]

166. Duvoisin, R.M.; Zhang, C.; Pfankuch, T.F.; O'Connor, H.; Quraishi, S.; Raber, J.; Gayet-Primo, J. Increased measures of anxiety and weight gain in mice lacking the group III metabotropic glutamate receptor mGluR8. Eur. J. Neurosci. 2005, 22, 425-436. (In English) [CrossRef]

167. Gasparini, F.; Bruno, V.; Battaglia, G.; Lukic, S.; Leonhardt, T.; Inderbitzin, W.; Laurie, D.; Sommer, B.; A Varney, M.; Hess, S.D.; et al. $(\mathrm{R}, \mathrm{S})$-4-phosphonophenylglycine, a potent and selective group III metabotropic glutamate receptor agonist, is anticonvulsive and neuroprotective in vivo. J. Pharmacol. Exp. Ther. 1999, 289, 1678-1687. (In English) [PubMed]

168. Erdmann, E.; Rupprecht, V.; Matthews, E.; Kukley, M.; Schoch, S.; Dietrich, D. Depression of release by mGluR8 alters Ca2+ dependence of release machinery. Cereb. Cortex 2012, 22, 1498-1509. (In English) [CrossRef] [PubMed]

169. Kammermeier, P.J. Constitutive activity of metabotropic glutamate receptor 7. BMC Neurosci. 2015, 16, 17. (In English) [CrossRef] [PubMed] 